\title{
Evaluating the Effectiveness of Negative Appeals Used in Emotional Marketing in Relation to Smoking Phenomenon in Egypt
}

\author{
Eman Wadie Abdel Halim ${ }^{1}$ \\ ${ }^{1}$ Business Administration, El Shorouk Academy, Cairo, Egypt \\ Correspondence: Eman Wadie Abdel Halim, Assistant Professor of Business Administration, El Shorouk \\ Academy, Cairo, Egypt.
}

Received: October 15, 2018

Accepted: November 9, 2018 Online Published: November 27, 2018

doi:10.5539/ijms.v10n4p160

URL: https://doi.org/10.5539/ijms.v10n4p160

\begin{abstract}
Negative emotional appeals are used frequently to change behaviours and direct them to serve the purposes of individuals or societies. Certain studies have shown that negative emotional appeals, which include guilt and fear, have the ability to change the behaviour of individuals. On the other hand, some argue for using positive emotion appeals to steer consumer behaviour instead of negative emotional appeals amidst continued debates weighing the effectiveness of warning messages that some government agencies or departments might compel producers to put on product packaging, which usually use fear or threat to positively change and alter consumer behaviour and raise their awareness of consumption risks. This article studies the effectiveness of certain warning messages that the Ministry of Health compels producers to write on cigarette packs; and reviews the effects of negative emotional appeals on a smoker's behaviour on both the short and the long term. The study concludes that reading these warning messages only managed to affect or change the behaviour of a limited percentage of $14.7 \%$ of the total number of smokers who have actually read them. The study also uncovered a negative correlation between smoking and both education level and income level; when levels of education and/or income increase, this brings about a relative decrease in smoking and a stronger desire to quit. It was also found that the male participants showed a particular interest in smoking imported cigarettes on a daily basis while the female participants showed no such interest in smoking a certain type of cigarettes.
\end{abstract}

Keywords: emotional appeal, consumer behavior, smoking, individual behavior, cautionary statements, purchasing behavior

\section{Introduction}

Some marketers employ behaviourist theories that draw upon negative emotional appeals to promote positive individual or collective behaviours, believing that these appeals are highly persuasive and have the ability to change consumer behaviour (Rogers' PMT, 1970); yet, these theories fail to explain emotional appeal effectiveness in changing consumption behaviour over time (Paolo et al., 2015). There might be a time gap between being exposed to a fear appeal and the desired behavioural effects; researchers usually focus on what happens to an individual while being exposed to a threat, instead of focusing on how fear (or threat) might affect the future decisions of consumers or how time delay might affect the effectiveness of fear appeal persuasiveness in changing consumer behaviour. In practice, the effects of fear appeal on attitudes and/or behaviours are measured immediately after exposure. It is not taken into consideration how fear appeals influence attitudes or behaviours over time or after a period of delay.

Some studies confirmed that fear and guilt have the ability to change consumption behaviour (Ajzen, 1991). Arousing fear is a means to promote precautionary motivation and self-protective action in order to change an individual's behaviour over time (Ruiter et al., 2014). Other scholars think that negative emotional appeals can backfire; they suggest that marketers should elicit positive emotions to positively change consumers' behaviours and decisions, like the desire to live or health benefits and the necessity of being healthy, instead of eliciting negative emotions (Witte, 1992).

In this paper, a questionnaire was designed and used as a research tool to collect data and information from participants after conducting a survey on a sample of (7) social marketing experts including: (4) academics and (3) marketing experts working in the Tobacco industry in Egypt. There were given the questionnaire after certain amendments were made. The 'yes' response rate for questionnaire clauses was $71.4 \%$ to $85.0 \%$. The public and 
private sectors employee was the sampling unit used to evaluate the effectiveness of warning messages written on cigarette packaging as a means to alter smokers' behaviours. The first part included demographic data identifying information about the smoking behaviour of the participants. The second part addressed 3 categories: smokers, non-smokers and individuals who quit smoking; it also reviewed some features of Egyptian smokers that are relevant to certain research variables: like types, brands and the average number of cigarettes that a person smokes per day. The study discussed the most important factors and root causes that guide consumer behaviour; it also evaluated the Egyptian household expenditure trend on tobacco by studying and analyzing the main trend of the average monthly expenditure on smoking and the main trend of the death rate from chest disease against general mortality that result from negative effects of smoking on the respiratory system.

The inductive and deductive methods were used for the purposes of this research paper. The results and the reciprocal and influential relations between research variables have been studied in order to offer recommendations in the light of these results to guide and help decision makers in the fight against the negative effects of smoking in a more realistic manner - a manner that would achieve community objectives amidst all the surrounding environmental changes that represent administrative challenges at the moment.

\section{Research Question}

Although some governments and consumer protection agencies pay great attention to placing warning messages, phrases or drawings on certain products' packaging to arouse fear and aversion into consumers' minds as a means to protect them and educate them on the risks posed by their wrong behaviours or consuming or purchase decisions like smoking; and despite the low quality of life and low income in some developing countries; statistics of 2015 showed that the average monthly household expenditure on smoking has reached USD 220 and that chest disease mortality is $9.5 \%$ of the overall mortality that year. The important question now is exploring the effectiveness of these phrases or messages on cigarette packaging. They are supposed to use fear and threat to change consuming behaviour in order to limit the smoking phenomenon which has numerous negative effects on individual health, the surrounding environment and national spending. Government spending on health and the arising mortality due to chest disease are just two examples of how smoking immensely burdens national spending. These burdens take a toll on the state's ability to maintain foreign currency reserves and direct its resources to feed development projects in order to raise the national income and in turn increase the individual's income and accomplish the desired social welfare.

\section{Literature Review}

This paper will employ Rogers' PMT model (Rogers, 1970) and his 1983 modified model which was used by previous researches in studying fear. It suggests that when people are confronted with fear or fear appeals that threaten their thinking or behaviour, they immediately engage in two parallel cognitive processes: (1) threat appraisal (how serious is the threat?) and (2) coping and facing appraisal (how equipped am I to cope with it?). The PMT model also suggested that a person's efficacy and his personal ability to deal with a threat on one hand, and their response efficacy which means their confidence in that the suggested action will help avoid the threat and limit its ramifications on the other are two of the most important processes that affect behaviour; The outcome of this complex cognitive process then influences individual behavioural intentions which may lead to behavioural changes on the short or the long run.

One of the most important relevant studies serving the purpose of this paper is the 2015 study conducted by Paolo and others which presented the elicitation-consumption framework to determine the right timing to use fear and guilt appeals. This study links how individuals handle negative emotional appeals and how it applies to the decision making process.

The inductive and deductive methods used for the purposes of this research separate between marketing communication and actual consumption of the product/service with a temporal delay between the two processes. The model attempts to link the time of emotional elicitation when warning or threatening messages are directed at the individual (Time 1) with the time of actual consumption when memory is at work to bring back the feeling of threat to affect emotions and shape consumption behaviour (Time 2). The study developed a consumption model to link those two times: the first, when a consumer remembers the negative emotional appeals to which they were exposed and predicting its effects on his consumption behaviour; the second, when recognition influences an individual's behaviour and directs them to either buy or not buy, whether or not they have been exposed to negative emotional appeals or realize the consequences of their harmful consumption behaviour; and regardless of possible feelings of guilt or fear that might result from the experience. The study also recommends employing narrative-based warning messages due to its efficacy when used as a persuasive style to convince consumers of the severity of their consumption behaviour. When reading or watching a persuasive attempt based 
on a story, consumers are absorbed into the narrative, leading to a stronger impact on their beliefs, a rich emotional experience that would positively affect their actual decision-making process and less likelihood of counter arguments on the consumer's part because the positive effect of this style on the consumer lasts longer. In Andrews et al. (2014), researchers found that exposure to appeals that use graphic images has a strong effect in delivering the warning message but the individual can get used to the negative appeal if it is repeated, which can minimize that effect. They also concluded that the background colour used in an appeal can increase the level of fear elicited; blue enhances fear elicitation compared to yellow for example. They confirmed that repeated exposures to or familiarity with a certain behaviour can minimize fear appeals persuasion. Kim et al. (2012) concluded a different opinion from the above; it confirmed that repeated exposures to or familiarity with a certain behaviour can make a non-threatening messages more effective than a threatening message. Chung and Ahn et al. (2013) concluded that the cultural background of the individual influences the persuasiveness of fear or threat appeals. It recommended the diversification and non-mainstreaming of negative appeals according to the different cultural backgrounds of individuals targeted with the campaigns. People from higher cultural backgrounds are best persuaded when the messages are addressed to a single addressee. In his 2013 study, Carruthers suggested that the personality of an individual influences the effectiveness of fear messages. Logical and intellectual individuals are less responsive to negative emotional appeals that seek to forcefully elicit fear. In Shehryar et al. (2005), researchers found that death-based fear appeals that employ reasoning and logic to prove that death is the inevitable end for everyone are more effective when used in warning messages that target people who uphold intellectual and philosophical values. Block (2015) confirmed that personality is the main determinant of the effectiveness of negative appeals; an independent person is more affected by warning messages than a dependent person. Griskevicius et al. (2009) confirmed that proof-based fear appeals are more persuasive than other appeals that offer no basis or evidence. Manyiwa et al. 2012 study suggests that stronger experiences of fear for oneself increase persuasion in negative appeals that use threat. Mowen (2004) proposed that personality traits influence the effectiveness of fear-based or threat-based advertisements. Introverts who feel the need to protect body resources give better fear responses. Jager and Eisend (2013) concluded that cooperative people with positive attitudes are more accepting of and persuaded by fear appeals than negative and uncooperative people. On another level, Morales et al. (2012) investigated the contents of warning messages. It confirmed that messages eliciting disgust and fear are more effective than fear-only appeals. Brennan and Binney 2010 study showed that the activation of self-protection processes, encouraging people and enhancing their belief in their abilities to protect themselves weaken appeals' effectiveness. Macharis et al. 2010 study established that individuals are sensitive to different elements of the appeal; the degree of the appeal's success depends on the effectiveness and strength of the words and phrases used in warning messages. Ruiter et al. (2010) showed that 'Loss framing' of the message stressing potential loss in a limited and short style is more persuasive in changing consumer behaviour. Lennon et al. (2010) proved that females are more persuaded by fear-based messages than males and that adolescents feel more fear when presented with anti-smoking appeals than older people (Ferguson \& Phau 2013).

Latour and Tanner (2003) concluded that people with children are more responsive to potential health threats. Tanner et al. (1991) said that recommended action that affects other people around the individual positively is more persuasive. Terblanche, Smit et al. (2010) concluded that fear-related personal experiences make the individual more vulnerable to the threat or fear appeals than others who have not experienced any strong fear sensation in their lives. This is opposed to the conclusion of Reardon (2006) who showed that individuals with past experiences with fear appeals are usually less responsive to fear eliciting messages. Florence (2008) confirmed that the tendency to seek strong sensations/experiences weakens the persuasiveness of fear appeals. Samu and Bhatnagr (2008) found that individuals are more influenced by fear appeals when discussed with friends than with strangers. This was also confirmed by Lorde (1994), that persuasion is increased when the appeal is delivered by acquaintances or members of the closer group.

Dickinson and Holmes (2008) confirmed that fear of social disapproval is more effective at generating response to negative emotional appeals than fear of physical harm, and that moderate appeals are more persuasive than high appeals. Reardon showed in his 2006 study that low-intensity fear-based appeals work better with high uncertainty-avoidant respondents than high-intensity appeals. In his 2000 study, O'Keefe concludes that while guilt is clearly effective in regulating interpersonal behaviour and compliance mechanisms in social life, recurrent persuasive guilt messages can backfire. It can force individuals to structure counter arguments to minimize the severity of warnings and negative emotional appeals, thus losing the ability to convince them of the possible risks of their consumption decisions. The study also concluded that moderate levels of threat are effective in changing and altering consumer behavior while Ruiter et al. (2004) suggested that strong appeals create stronger guilt and fear compared to moderate appeals. De Hoog et al. (2007) concluded that individuals 
targeted with negative emotional appeals can feel heightened vulnerability that causes a sense of helplessness and inability to change their negative behaviour.

From the above, we conclude that the most important results from relevant previous studies to the purposes of this paper show that there is a there is a relationship between the strength of threat and individual fear of the negative effects of certain consumption decisions. Threat strength is the main inducer of fear. In other words, there is a positive relationship between degree of danger sensation and fear of the consumption decision. Theories that study responsiveness suggest that high threats can lead to maladaptive responses. The most persuasive threats are those of clear personal relevance, supported by an action recommendation deemed achievable. Also, repeated exposure to appeals that use graphic images warning against smoking risks can gradually lose effect on consumers and cause them to lose the urge to quite over time due to the repetitiveness of the same appeal. It is also evident that temporal considerations have a huge role in this process; some people may resist feelings of fear at the beginning then come around to embracing them. Noted as well is the significance of temporal delay between the two elements of communication: time of exposure to negative emotional appeals and time of consumption of product/service in, which can weaken the effectiveness of warning messages allowing individuals to construct counter behaviours, to forget or to lose the fear urge.

\section{Study Objectives}

1) Evaluating the effectiveness of warning messages on cigarette packaging in changing consumer behaviour.

2) Exploring the most influential factors and reasons behind an individual's decision to continue smoking.

3) Evaluating household expenditure on smoking by studying and analyzing the main trend for the average monthly spending on smoking.

4) Studying the main trend of chest disease mortality compared to overall mortality despite employing warning messages as a means of raising awareness against the negative effects of smoking on the respiratory system.

5) Analyzing the characteristics and personal features of the Egyptian smoker in general considering certain variables related to smoking (average daily number of cigarettes that a person smokes, types and brands of cigarettes, reasons for smoking... etc.)

\section{Study Hypotheses}

1) There is no relationship between the demographic variables of an individual and their attitude towards smoking.

2) There is no relationship between being interested in reading the warning messages on cigarette packs and an individual's attitudes and behaviour towards smoking.

3) Warning messages on cigarette packs have no effect on limiting smoking as a phenomenon, despite all the negative effects it has on people.

4) Demographic characteristics of the smoker have no effect on smoking habits (daily number of cigarettes, smoking a certain brand of cigarettes, reasons for smoking, reading warning messages, being interested in certain messages more than others)

5) There is no relationship between health problems that smokers suffer as a result of smoking and the decision to continue smoking whilst being fully aware of these problems.

\section{Population and Sample}

\subsection{First: Population}

They are employees in the public and governmental sectors in Greater Cairo area as they have the financial capability to spend on smoking among other things; and also because that this community is homogeneous and there are almost no individual differences between its members. Moreover, there are valid statistics for this community (their number is 3604755 employees) and it is characterized by the relative availability of stability element.

\subsection{Second: Research Sample}

The sampling unit is the employee who works at one of the firms in the governmental and public sectors. Since statistics are available in these sectors, this count varies from time to time, as some of the employees reach retirement age or as a result of new placement systems employed by the state, especially after the two revolutions of January $25^{\text {th }}$ and June $30^{\text {th }}$. Thus, the Researcher has considered that this count is an approximate and estimated number and doesn't represent the precise number. That is why the Researcher has used sampling 
tables. Therefore, it has been concluded that the representative sample for the population, with a sampling margin error of 5\%, includes 400 sample units who have been contacted via their employers in agencies or companies. After checking the questionnaires, it was found that there are 20 incomplete forms; so, the correct response rate is approximately $97.5 \%$. In addition, the systematic random sampling method has been used in selecting research sample units.

\subsection{Some Demographic Characteristics of Study Sample}

Table 1 shows some demographic characteristics of the study sample.

The results in Table 1 confirmed that most of the research sample units are youth of an average age of 33 years. There is higher concentration in two age groups: "less than 25 years" and "35 to 40 years". In addition, males are dominant in numbers with a percentage of 82.4 of the total sample. Moreover, both "University Degree" education level and "Less than 2000" (low) income level were the highest in each of their categories, coming at $62.4 \%$ and $41.8 \%$ respectively of the total research sample. These results corresponded to the announcement of the Central Agency for Public Mobilization and Statistics which concluded that the total number of smokers in Egypt between 25 and 44 years of age was more than $60 \%$, and that the majority of that percentage was males $(41 \%)$.

Table 1. Descriptive statistics of research sample

\begin{tabular}{llll}
\hline Demographic Variables & & Frequency & $\%$ \\
\hline \multirow{4}{*}{ Age Groups } & Less than 25 & 72 & 18.9 \\
& $25-$ & 83 & 21.8 \\
& $30-$ & 68 & 17.9 \\
& $35-$ & 79 & 20.8 \\
Gender & Over $40\left(33.42^{(1)}, 9.39^{(2)}\right)$ & 78 & 20.6 \\
\hline \multirow{4}{*}{ Education Level } & Males & 313 & 82.4 \\
& Females & 67 & 17.6 \\
\hline & Basic & 28 & 7.4 \\
& Intermediate & 56 & 14.7 \\
& University Degree & 237 & 62.4 \\
Income Level & Postgraduate Degree & 59 & 15.5 \\
& Less than 2000 & 159 & 41.8 \\
& $2000-$ & 105 & 27.6 \\
& $3000-$ & 53 & 13.9 \\
& $4000-$ & 45 & 11.8 \\
\hline
\end{tabular}

(1) Refers to the average age of research sample.

(2) Denotes to Standard Deviation of the age of the sample.

\section{Testing Hypotheses}

\subsection{Testing the First Hypothesis}

$\mathrm{H}_{1} \quad$ There is no relationship between the demographic variables of an individual and their attitude towards smoking.

To study the first hypothesis $\left(\mathbf{H}_{\mathbf{1}}\right)$, the Researcher used Crosstabs in addition to Chi-square test. Table 2 presents the results.

The Results of Table 2 confirmed the existence of a relationship between certain demographic variables and the individual's smoking status as follows:

Education level: The value of Chi-square test $($ Chi-square $=13.535)$ confirms the statistical significance at 0.05 level of significance and 6 degrees of freedom. Also the frequency and percentage distribution stress that the higher the education level, the higher the tendency to quit smoking or the attempt to quit.

Income level: The value of Chi-square test (Chi-square $=26.218)$ confirms the statistical significance at 0.01 level of significance and 8 degrees of freedom. Also the frequency and percentage distribution stresses that the higher the income level, the higher the desire to stop smoking or refusal to smoke.

As for the results for Age distribution and Gender, the results confirm that there is no relationship between demographic variables and smoking status; Chi-square test value did not reach the extent that makes it significant 
at a 0.05 level at least.

Therefore, we can accept the first hypothesis of the study at the level of age and gender groups' results, and reject it at the level of Education and Income levels results, which means that we partially accept the first hypothesis.

Table 2. Results for the relationship between demographic variables and the attitude towards smoking

\begin{tabular}{|c|c|c|c|c|c|c|}
\hline \multirow{2}{*}{ Demographi } & \multirow{2}{*}{ c Variables } & \multicolumn{3}{|c|}{ Smoking Status } & \multirow{2}{*}{$\begin{array}{l}\text { Chi-square Test } \\
(d f)\end{array}$} & \multirow{2}{*}{$\begin{array}{l}\text { Level } \\
\text { of Significance }\end{array}$} \\
\hline & & Smoker & Non-smoker & Was a smoker & & \\
\hline \multirow{10}{*}{$\begin{array}{l}\text { Age } \\
\text { Groups }\end{array}$} & Less than 25 & 31 & 32 & 9 & \multirow{10}{*}{$\begin{array}{l}8.26 \\
(8)\end{array}$} & \multirow{10}{*}{$\begin{array}{l}0.408 \\
\text { Non-significant }\end{array}$} \\
\hline & $\%$ & $16.8^{(1)}$ & $21.8^{(1)}$ & $18.4^{(1)}$ & & \\
\hline & $25-$ & 38 & 36 & 9 & & \\
\hline & $\%$ & $20.7^{(1)}$ & $24.5^{(1)}$ & $18.4^{(1)}$ & & \\
\hline & $30-$ & 39 & 24 & 5 & & \\
\hline & $\%$ & $21.2^{(1)}$ & $16.3^{(1)}$ & $10.2^{(1)}$ & & \\
\hline & $35-$ & 36 & 31 & 12 & & \\
\hline & $\%$ & $19.6^{(1)}$ & $21.1^{(1)}$ & $24.5^{(1)}$ & & \\
\hline & Over 40 & 40 & 24 & 14 & & \\
\hline & $\%$ & $21.7^{(1)}$ & $16.3^{(1)}$ & $28.6^{(1)}$ & & \\
\hline \multirow{4}{*}{ Gender } & Males & 154 & 118 & 41 & \multirow{4}{*}{$\begin{array}{l}1.725 \\
(2)\end{array}$} & \multirow{4}{*}{$\begin{array}{l}0.696 \\
\text { Non-significant }\end{array}$} \\
\hline & $\%$ & $49.2^{(2)}$ & $37.7^{(2)}$ & $13.7^{(2)}$ & & \\
\hline & Females & 30 & 29 & 8 & & \\
\hline & $\%$ & $44.8^{(2)}$ & $43.3^{(2)}$ & $11.9^{(2)}$ & & \\
\hline \multirow{8}{*}{$\begin{array}{l}\text { Education } \\
\text { Level }\end{array}$} & \multirow{2}{*}{ Basic } & 19 & 4 & 5 & \multirow{8}{*}{$\begin{array}{l}13.53 \\
(6)\end{array}$} & \multirow{8}{*}{$\begin{array}{l}0.035 \\
\text { Significant at level }(0.05)\end{array}$} \\
\hline & & $10.3^{(1)}$ & $2.7^{(1)}$ & $10.2^{(1)}$ & & \\
\hline & \multirow{2}{*}{ Intermediate } & 32 & 20 & 4 & & \\
\hline & & $17.4^{(1)}$ & $13.6^{(1)}$ & $8.2^{(1)}$ & & \\
\hline & \multirow{2}{*}{ University } & 112 & 94 & 31 & & \\
\hline & & $60.9^{(1)}$ & $63.9^{(1)}$ & $63.3^{(1)}$ & & \\
\hline & \multirow{2}{*}{ Postgraduate } & 21 & 29 & 9 & & \\
\hline & & $11.4^{(1)}$ & $19.7^{(1)}$ & $18.4^{(1)}$ & & \\
\hline \multirow{10}{*}{$\begin{array}{l}\text { Income } \\
\text { Level }\end{array}$} & Less than & 85 & 56 & 18 & \multirow{10}{*}{$\begin{array}{l}26.218 \\
(8)\end{array}$} & \multirow{10}{*}{$\begin{array}{l}0.001 \\
\text { Significant at level }(0.01)\end{array}$} \\
\hline & 2000 & $46.2^{(1)}$ & $38.1^{(1)}$ & $36.7^{(1)}$ & & \\
\hline & & 55 & 42 & 8 & & \\
\hline & $2000-$ & $29.9^{(1)}$ & $28.6^{(1)}$ & $16.4^{(1)}$ & & \\
\hline & \multirow{2}{*}{$3000-$} & 21 & 22 & 10 & & \\
\hline & & $11.4^{(1)}$ & $15^{(1)}$ & $20.4^{(1)}$ & & \\
\hline & \multirow{2}{*}{$4000-$} & 21 & 19 & 5 & & \\
\hline & & $11.4^{(1)}$ & $12.9^{(1)}$ & $10.2^{(1)}$ & & \\
\hline & \multirow{2}{*}{ Over 6000} & 2 & 8 & 8 & & \\
\hline & & $1.1^{(1)}$ & $5.4^{(1)}$ & $16.3^{(1)}$ & & \\
\hline
\end{tabular}

(1) Indicates that the percentage has been calculated based on the smoking status.

${ }^{(2)}$ Indicates that the percentage has been calculated based on gender.

\subsection{Testing the Second Hypothesis}

$\mathrm{H}_{2}$ There is no relationship between being interested in reading the warning messages written on cigarette packs and an individual's attitudes and behaviour towards smoking. 
Table 3. Results for the relationship between reading warning messages on cigarette packs and smoking status of the individual

\begin{tabular}{|c|c|c|c|}
\hline \multirow{2}{*}{ Reading Warning Phrases } & \multicolumn{3}{|l|}{ Smoking Status } \\
\hline & Yes & No & Was a smoker \\
\hline Yes & 162 & 105 & 46 \\
\hline$\%$ & (2) $51.8 \quad 88.0$, & (2) 33.571 .4 , & ${ }^{(2)} 14.793 .9$, \\
\hline No & 6 & & - \\
\hline$\%$ & (2) 28.63 .3 , & (2)71.4 10.2, & - \\
\hline Sometimes & 16 & 27 & 3 \\
\hline$\%$ & (2) $34.8 \quad 8.7$, & (2) 58.718 .4 , & ${ }^{(2)} 6.5 \quad 6.1$, \\
\hline $\begin{array}{l}\text { Chi-square test value }=21 \\
\text { Chi-square test value }^{(1)}=8\end{array}$ & $\begin{array}{l}\text { Degrees of freed } \\
\text { Degrees of freed }\end{array}$ & $\begin{array}{l}=4, \text { Significanc } \\
=2, \text { Significanc }\end{array}$ & $\begin{array}{l}\mathrm{vel}=0.000(\text { significant at } 0.01 \text { level }) \\
\mathrm{vel}=0.017 \text { (significant at } 0.05 \text { level })\end{array}$ \\
\hline
\end{tabular}

${ }^{(1)}$ The modified value of Chi-square test is calculated after combining the results of the two columns (No) and (Was a smoker), so that we can use Chi-square test.

${ }^{(2)}$ The percentage for the total value of every column and row has been calculated respectively.

To test the second hypothesis $\left(\mathrm{H}_{2}\right)$, the Researcher used Crosstabs in addition to Chi-square test. Table 3 presents the results.

The results in Table 3 confirmed the existence of a relationship between reading warning messages and an individual's smoking status; the Chi-square test value (modified Chi-square value $=8.134$ ) confirms the statistical significance at $5 \%$ level, with 6 degrees of freedom. It was noticed that the research units who read warning messages were mostly smokers, where their percentage is $88.0 \%$ of total smokers. Results also showed that $15 \%$ of those who read the warning messages did in fact quit smoking; the fact that they read the statements could be one of the main reasons behind this positive change in behaviour.

These results agree with the results of Kim et al. (2014), Kessels et al. (2014) and Andrews et al. (2014); these studies all confirmed that repeated exposure to (or familiarity with) a certain behaviour could minimize the effect of fear appeals; heavy long-term smoking lowers smokers' fear levels because of the long experience they accumulate and the repeated exposure to the behaviour. Therefore, we can definitely and completely reject the second hypothesis.

\subsection{Testing the Third Hypothesis}

$\mathrm{H}_{3}$ Warning messages on cigarette packs have no effect on limiting smoking as a phenomenon, despite all the negative effects it has on people.

To test the third hypothesis $\left(\mathrm{H}_{3}\right)$, the Researcher used some descriptive measures, represented in numbers and percentage, in addition to using Trend Analysis, during the period of 2000-2015, on the level of:

The percentage of deaths caused by chest diseases against general mortality,

The average monthly household expenditure on smoking in dollars,

The following are the results for testing the third hypothesis.

\section{Results of Descriptive Statistics}

\subsection{Descriptive Statistics of the Non-smokers Sample}

The descriptive statistics in Table 4 confirmed, by numbers and percentages, for each element, that the most important reason for not smoking in the first place is disliking its taste, followed by health reasons, then getting an advice from someone, then the slogans written on cigarette packs, and at the end the financial reasons.

Table 4. Descriptive statistics results for the reasons for not smoking (non-smokers)

\begin{tabular}{llll}
\hline Reasons for not smoking & Number & $\%$ & Ranking \\
\hline I did not like the taste & 39 & 26.9 & 1 \\
Following an advice from someone & 30 & 20.7 & 2 \\
Knowing a person who got sick/is dead as a result of smoking & 25 & 17.2 & 3 \\
Health reasons & 33 & 22.8 & 4 \\
Financial reasons & 19 & 13.8 & 5 \\
Slogans of advice and guidance written on cigarette packs & 23 & 15.9 & 6 \\
\hline
\end{tabular}




\subsection{Descriptive Statistics of the Ex-smokers Sample (Smokers Who Quit Smoking)}

The descriptive statistics in Table 5 confirmed, by numbers and percentages, for each element, that the most important reason for not quitting smoking is getting an advice from someone, followed by health reasons, then knowing a person who is dead as a result of smoking, and finally the warning information written on cigarette packs (smoking is very harmful to health - Smoking causes cardiovascular disease - smoking is harmful to children - Keep your children away from smoking).

Table 5. Descriptive statistics results for the reasons for quitting smoking (smokers who quit)

\begin{tabular}{llll}
\hline Reasons for not smoking & Number & $\%$ & Ranking \\
\hline Health reasons & 17 & 36.2 & 2 \\
Following an advice from someone & 21 & 44.7 & 1 \\
Financial reasons & 12 & 25.5 & 3 \\
Knowing a person who got sick/is dead as a result of smoking & 10 & 21.3 & 4 \\
Slogans of advice and guidance written on cigarette packs & 3 & 6.4 & 6 \\
\hline
\end{tabular}

\section{Results of Trend Analysis}

\subsection{Studying the Percentage of Deaths caused by Chest Diseases Against Total Deaths}

\subsubsection{Studying the Scatter Diagram}

Figure 1 represents the Scatter Diagram related to studying the relationship between the percentage of deaths caused by chest diseases against total deaths, which is represented on the vertical axis, and the years starting from the beginning of the current century (2000-2017), which are represented on the horizontal axis.

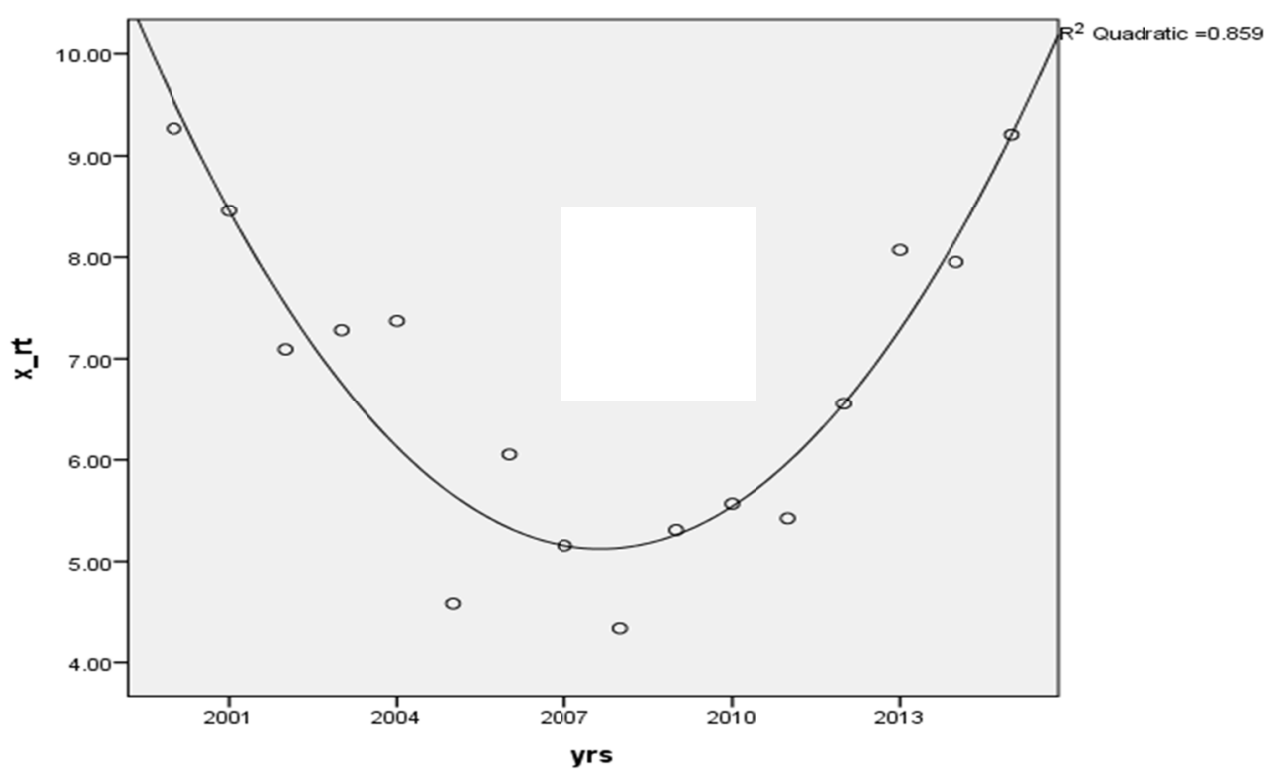

Figure 1. Scatter diagram of trend analysis of chest diseases deaths as a percentage of total deaths

The above Figure shows that the trend analysis is taking the mathematical Quadratic Form, which is confirmed by the results of Scatter Diagram; where the curve of Quadratic Form is close to most of these observations, thanks to applying the coefficient of determination standard which equals $\left(\mathrm{R}^{2}=76.0 \%\right)$. 


\subsubsection{Estimating the Coefficients and Tests of the Model}

Table 6. Results of the trend analysis related to studying the percentage of chest diseases deaths against total deaths

\begin{tabular}{lllll}
\hline Coefficients and Tests & \multicolumn{4}{l}{ The Model and its Tests } \\
\hline $\begin{array}{l}\text { Model Coefficients } \\
\text { Coefficients Tests }\end{array}$ & Xrt $=$ & $\begin{array}{l}9.097 \\
\left(17.166^{* *}\right)\end{array}$ & $\begin{array}{l}-0.907 \mathrm{t} \\
\left(-6.273^{* *}\right)\end{array}$ & $\begin{array}{l}+0.056 \mathrm{t}^{2} \\
(6.801 * *)\end{array}$ \\
\hline \multirow{2}{*}{ Model Tests } & F-rati $=23.735^{* *}$, d.f $=(2,15)$, Sig. $=0.000(\mathrm{P}<0.01)$ \\
& S.E $=0.834 \mathrm{R}^{2}=76.0 \%$ & & \\
\end{tabular}

** Refers to the significance of both tests $\mathrm{F}, \mathrm{T}$ at 0.01 level of significant.

From the previous results of the Scatter Diagram, the regression coefficients are estimated as mentioned in Table 6.

The results in Table 6 confirmed the significance of regression model, where " $F$ " test value equals $(F=39.571)$; that confirms the statistical significance at level of 0.01 with 2 and 13 degrees of freedom. The results also confirmed that the time (independent variable) explains the changing of the percentage of deaths caused by chest diseases against total death rate (dependent variable), representing about $86 \%$. Moreover, the results confirmed that the impact of the time is positive. Also, the value of standard error was limited to some extent.

In this regard, the study of Shehryar and Hunt (2005) pointed out that warning appeals that use death as a threat in a rational manner only affect individuals who possess intellectual and philosophical values. This study, of course, speaks to individuals from developed countries; and unfortunately, in third world countries, communication that is based on evidence is not always the most successful approach in convincing people or changing their attitudes. Most people are rarely convinced by means of reason and logic.

\subsection{Studying the Average Monthly Household Expenditure on Smoking in Dollars}

\subsubsection{Studying the Scatter Diagram}

Figure 2 is the Scatter Diagram of studying the average household expenditure on smoking in dollars during the period starting from the beginning of this century till now (2000-2017).

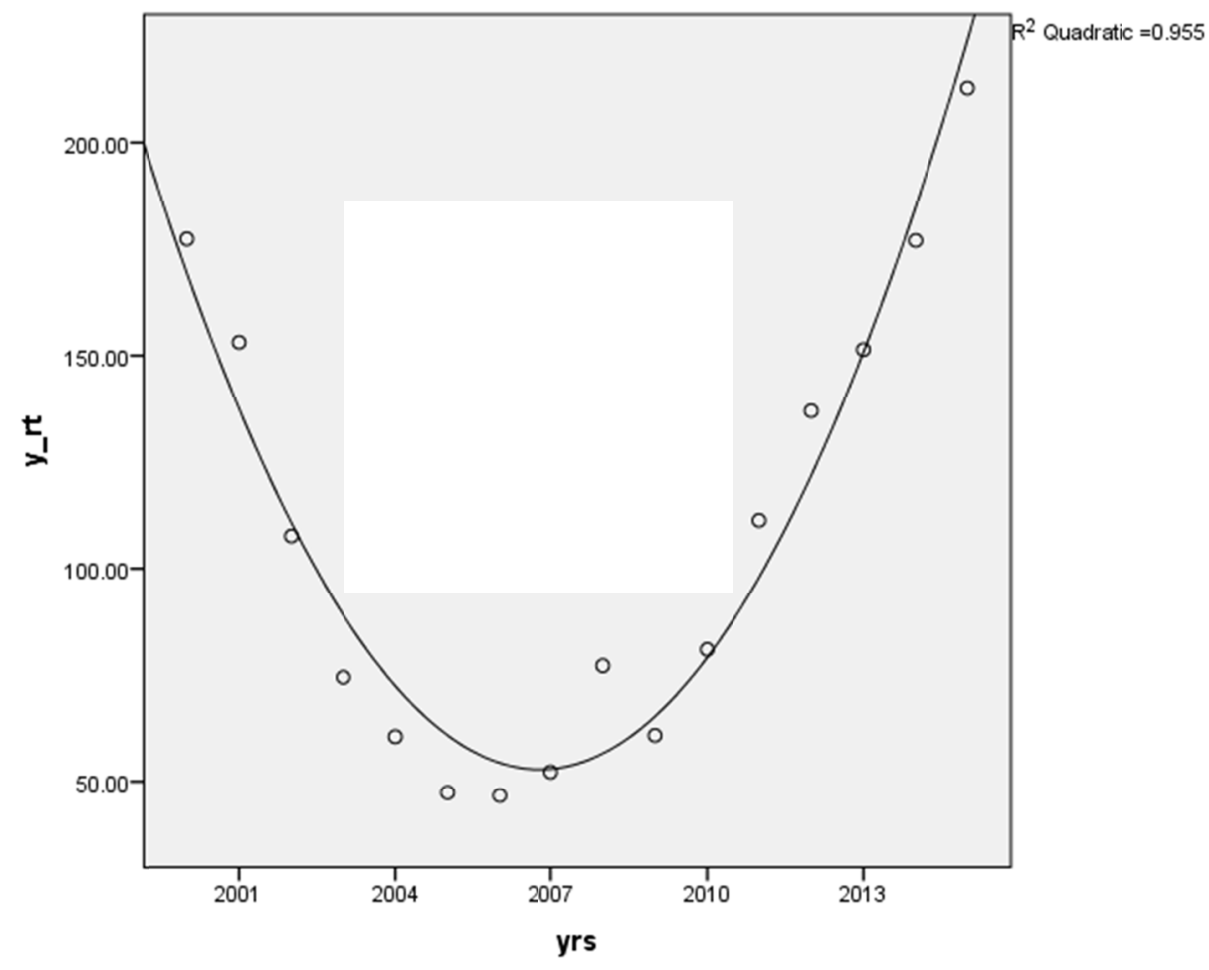

Figure 2. Scatter diagram of trend analysis of the average household expenditure on smoking 
The above Figure shows that that the trend analysis is taking the mathematical Quadratic Form, which is confirmed by the results of Scatter Diagram; whereas the curve of Quadratic Form is close to most of these observations, thanks to applying the standard coefficient of determination that equals $\left(\mathrm{R}^{2}=85.5 \%\right)$.

\subsubsection{Estimating the Coefficients and Tests of Model}

Table 7. Results of the trend analysis related to studying the average monthly expenditure on smoking in dollars

\begin{tabular}{lllll}
\hline Coefficients and Tests & \multicolumn{4}{l}{ The Model and its Tests } \\
\hline $\begin{array}{l}\text { Model Coefficients } \\
\text { Coefficients Tests }\end{array}$ & Y_rt $=$ & $\begin{array}{l}153.631 \\
\left(10.230^{* *}\right)\end{array}$ & $\begin{array}{l}-25.458 \mathrm{t} \\
\left(-6.215^{* *}\right)\end{array}$ & $\begin{array}{l}+1.826 \mathrm{t}^{2} \\
\left(7.850^{* *}\right)\end{array}$ \\
\hline \multirow{2}{*}{ Model Tests } & F-rati $=44.290^{* *}$, d.f $=(2,15)$, Sig. $=0.000(\mathrm{P}<0.01)$ & \\
& S.E $=23.641 \mathrm{R} 2=85.5 \%$ & & \\
\hline
\end{tabular}

** Refers to the significance of both tests "F" and "T" at the significance level of 0.01 .

From the previous results of the Scatter Diagram, the regression coefficients are estimated as mentioned in Table 7. The results in Table 7 confirmed the significance of regression model, where " $F$ " test value equals $(F=$ 44.290), which confirms the statistical significance at level of 0.01 with 2 and 15 degrees of freedom. The results also confirmed that the explanatory level that occurs on the independent variable, represented by the time, is about $85.5 \%$. Moreover, the results confirmed that the impact of this variable on the trend analysis is positive, whereas the value of standard error was limited to a great extent.

Therefore, it is evident that there is a positive impact of the percentage of chest diseases deaths against total deaths and the average household expenditure on smoking in dollars, which reflects an expected increase in both in the near future due to the new policy approach employed by the Ministry of Health to reducing the phenomenon of smoking. This in turn means that these warning messages do not achieve their intended goals. Thus, we can accept the validity of the third hypothesis.

\section{Testing the Fourth Hypothesis}

$\mathrm{H}_{4}$ Demographic characteristics of the smoker have no effect on their smoking habits (average daily number of cigarettes, smoking a certain brand, reasons for smoking, reading warning messages)

To test the fourth hypothesis $\left(\mathrm{H}_{4}\right)$, it has to be broken down into these sub-hypotheses:

\section{Sub-hypothesis 1:}

There are no statistically significant differences between the average daily number of cigarettes and some demographic characteristics of the smokers' sample (Age Groups, Gender, Education Level, Income Level).

\section{Sub-hypothesis 2:}

There is no relationship between choosing a certain brand of cigarettes and some demographic characteristics of the smokers' sample (Age Groups, Gender, Education Level, Income Level).

\section{Sub-hypothesis 3:}

There is no relationship between reasons for smoking and some demographic characteristics of the smokers' sample (Age Groups, Gender, Education Level, Income Level).

\section{Sub-hypothesis 4:}

There is no relationship between reading warning messages on cigarettes packs and some demographic characteristics of the smokers' sample (Age Groups, Gender, Education Level, Income Level).

\section{Sub-hypothesis 5:}

There are no statistically significant differences regarding the different effects of some warning messages written on cigarette packs when measured against certain demographic characteristics of the smokers' sample (Age Groups, Gender, Education Level, Income Level).

Since the variables of the previous 5 hypotheses differ in nature, a number of different statistical methods were used in order to accommodate each and every variable and test the hypotheses correctly.

\section{Results for Testing the Fourth Hypothesis}

\subsection{The Results of Testing Sub-hypothesis 1 of the Fourth Hypothesis}

"There are no statistically significant differences in the average daily number of cigarettes according to some demographic characteristics of the smokers' sample (Age Groups, Gender, Education Level, Income Level)" 
Table 8a. Results of differences in the average daily number of cigarettes according to certain demographic variables in the smokers sample

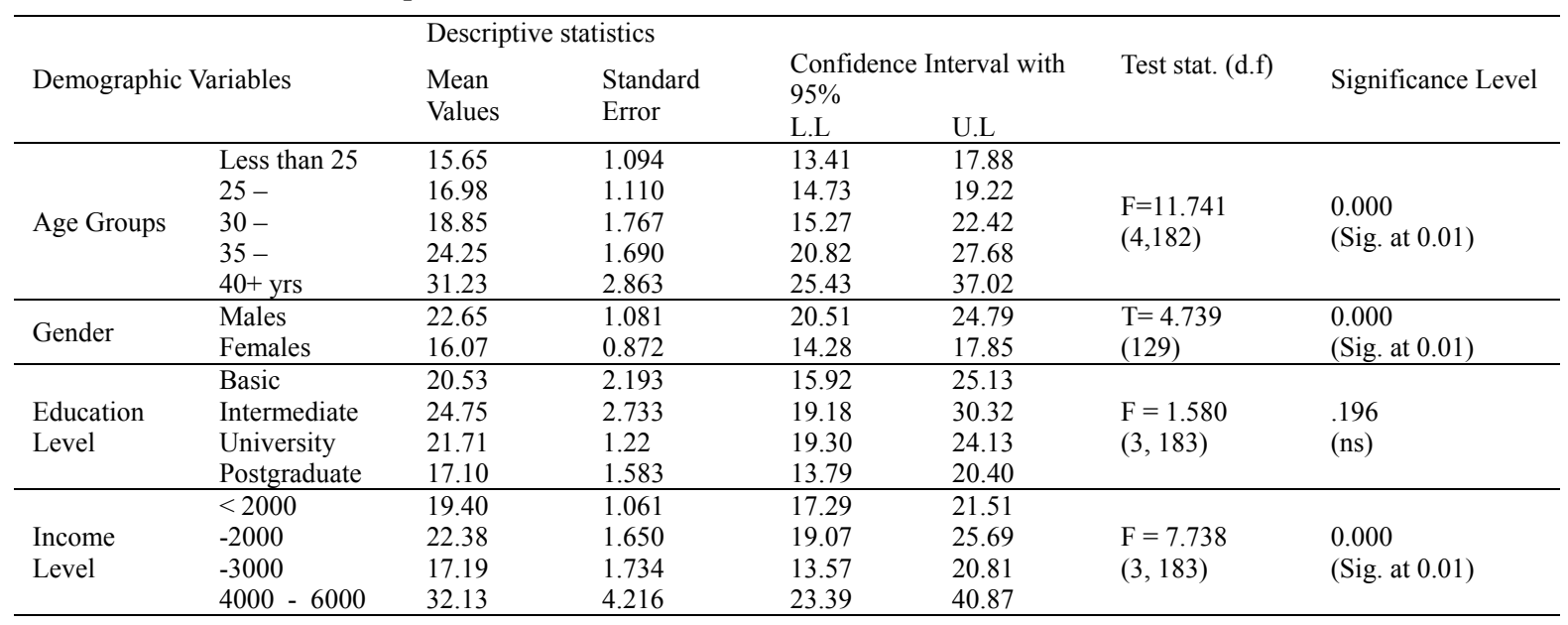

Table 8b. Results of Tukey's test (multiple comparisons) for the number of smoked cigarettes according to age groups

\begin{tabular}{llllll}
\hline Age groups & Less than 25 & $25-$ & $30-$ & $35-$ & $40+$ yrs \\
\hline Less than 25 & --- & $1.330^{(1)}$ & $3.201^{(1)}$ & $8.605^{*(1)}$ & $15.580^{*(1)}$ \\
$25-$ & --- & $1.871^{(1)}$ & $7.274^{(1)}$ & $14.249^{(1)}$ \\
$30-$ & & --- & $5.404^{(1)}$ & $12.379^{(1)}$ \\
$35-$ & & & --- & $6.975^{(1)}$ \\
$40+$ yrs & & & & & --- \\
\hline
\end{tabular}

* Indicates that there is a significant difference between the two groups.

(1) Refers to the difference between the means of two groups.

Table 8c. Results of Tukey's test (multiple comparisons) for the number of smoked cigarettes according to income level

\begin{tabular}{lllll}
\hline Income Level & Less than 2000 & -2000 & $3000-$ & $6000-4000$ \\
\hline Less than 2000 & --- & 2.984 & 2.207 & $12.733^{*}$ \\
$2000-$ & -- & 5.191 & $9.749^{*}$ \\
$3000-$ & & --- & $14.940^{*}$ \\
$4000-6000$ & & & & --- \\
\hline
\end{tabular}

* Indicates that there is a significant difference between the two groups.

(1) Refers to the difference between the means of two groups.

To test Sub-hypothesis 1 of the fourth hypothesis, the Researcher used statistical data description, One-Way Analysis of Variance and Tukey's test for Multiple Comparisons, in order to confirm the significance of the Analysis of Variance results. Table 8a, Table 8b, Table 8c show the results of testing Sub-hypothesis 1 of Hypothesis 4.

The results in the three tables confirmed the existence of differences in the number of smoked cigarettes according to the following demographic variables:

1) Age Groups: the test value of the one-way analysis of variance $(F=11.741)$ confirms the statistical significance at the level of 0.01 with 4.182 degrees of freedom (Table 8a). Tukey's test of multiple comparisons shows that these differences are between the two groups of young age: "less than 25 years old" and " 25 years to less than 30 years" and the two groups of older age to a certain extent: " 35 years to less than 40 years" and "40 years and more". In addition, there are statistically significant differences between the two Age Groups: "30 years" and " 40 years and more" (Table 8b). The descriptive statistics in Table (8a) show that these differences are in favor of Young Age Groups, which are confirmed by the mean values of the number of smoked cigarettes per day. These results correspond to Ferguson and Phau's 2013 study, which proved that teenagers experience more fear when they are exposed to anti-smoking appeals than older people. 
2) Gender: the test value of two independent samples $(\mathrm{T}=4.739)$ is significant at 0.01 the level of significance with 129 degrees of freedom. The descriptive statistics confirms that these differences are in favor of females, as emphasized by the mean values in Table 8a. These results correspond to Bhatnagar 2008 and Lennon et al. 2010 which were conducted in foreign settings and concluded that women are more susceptible to fear-based appeals than men.

3) Income Level: the test value of the one-way analysis of variance $(F=7.738)$ is significant at 0.01 level of significance with 3,183 degrees of freedom (Table 8a). Tukey's test (multiple comparisons) shows that these differences are between the top level of income which is " 4000 to less than 6000 " and all other income levels: "less than 2000", "2000 to less than 3000" and "3000 to less than 4000" (Table 8c). These differences are in favor of the low and middle income levels as emphasized by the descriptive statistics of Table 8a.

4) Education Level: results confirmed that there are no statistically significant differences between the four levels of education, where "F" value test didn't reach a significant level at a minimum of 0.05 .

Based on the previous results, the Researcher stresses the necessity of diversifying these warning messages to intelligently target and attempt to persuade different individuals from different cultural backgrounds. This also highlights the fact that the persuasive power of the statement is affected to a great extent by the individual's self-care and fear for their own welfare, which was confirmed earlier by Chung et al. 2013 and Lee et al. 2012. Manyiwa and Brennan 2012 and Griskevicius et al. 2009 found as well that fear appeals that are based on reasoning and evidence are far more convincing. Finally, the findings of this research on the average daily number of cigarettes ( 6 to 21 ) showed that the number corresponds to some degree to the number announced by the Central Agency for Public Mobilization and Statistics (15 to 24).

\subsection{The Results of Testing Sub-hypothesis 2 of the Fourth Hypothesis}

"There is no relationship between choosing a certain brand of cigarettes and some demographic characteristics of the smokers sample (Age groups, gender, education level, income level."

Table 9. Results of the relationship between some demographic variables and smokers' interest in smoking a specific brand

\begin{tabular}{|c|c|c|c|c|c|c|}
\hline \multicolumn{2}{|c|}{ Demographic Variables } & \multirow{2}{*}{$\begin{array}{l}\text { No specific brand } \\
4\end{array}$} & \multirow{2}{*}{$\begin{array}{l}\text { Local } \\
12\end{array}$} & \multirow{2}{*}{$\begin{array}{l}\text { Imported } \\
15\end{array}$} & $\begin{array}{l}\text { Chi-square Test } \\
\text { (d.f) }\end{array}$ & $\begin{array}{l}\text { Significance } \\
\text { Ratio }\end{array}$ \\
\hline \multirow{10}{*}{ Age Groups } & Less than 25 years & & & & \multirow{10}{*}{$\begin{array}{l}31.448 \\
(8)\end{array}$} & \multirow{10}{*}{$\begin{array}{l}0.000 \\
\text { (Significant a } \\
0.01)\end{array}$} \\
\hline & $\%$ & $14.3^{(1)}$ & $21.8^{(1)}$ & $14.9^{(1)}$ & & \\
\hline & $25-$ & 2 & 3 & 33 & & \\
\hline & $\%$ & $7.1^{(1)}$ & $5.5^{(1)}$ & $32.7^{(1)}$ & & \\
\hline & $30-$ & 7 & 7 & 25 & & \\
\hline & $\%$ & $25^{(1)}$ & $12.7^{(1)}$ & $24.8^{(1)}$ & & \\
\hline & $35-$ & 9 & 16 & 11 & & \\
\hline & $\%$ & $32.1^{(1)}$ & $29.1^{(1)}$ & $10.9^{(1)}$ & & \\
\hline & Over 40 years & 6 & 17 & 17 & & \\
\hline & $\%$ & $2.14^{(1)}$ & $30.9^{(1)}$ & $16.8^{(1)}$ & & \\
\hline \multirow{4}{*}{ Gender } & Male & 20 & 51 & 83 & \multirow{4}{*}{$\begin{array}{l}6.546 \\
(2)\end{array}$} & \multirow{4}{*}{$\begin{array}{l}0.038 \\
\text { (Significant a } \\
0.05)\end{array}$} \\
\hline & $\%$ & $13.0^{(2)}$ & $33.1^{(2)}$ & $53.9^{(2)}$ & & \\
\hline & Female & 18 & 4 & 8 & & \\
\hline & $\%$ & $60.0^{(2)}$ & $13.3^{(2)}$ & $26.7^{(2)}$ & & \\
\hline \multirow{4}{*}{$\begin{array}{l}\text { Education } \\
\text { Level }\end{array}$} & Basic/Intermediate & 12 & 30 & 9 & \multirow{4}{*}{$\begin{array}{l}40.792 \\
\text { (2) }\end{array}$} & \multirow{4}{*}{$\begin{array}{l}0.000 \\
\text { (Significant a } \\
0.01)\end{array}$} \\
\hline & $\%$ & $42.9^{(1)}$ & $54.5^{(1)}$ & $8.9^{(1)}$ & & \\
\hline & University/Postgraduate & 16 & 25 & 92 & & \\
\hline & $\%$ & $57.1^{(1)}$ & $45.5^{(1)}$ & $91.9^{(1)}$ & & \\
\hline \multirow{6}{*}{ Income Level } & Less than 2000 & 14 & 28 & 43 & \multirow{6}{*}{$\begin{array}{l}3.206 \\
(4)\end{array}$} & \multirow{6}{*}{$\begin{array}{l}0.524 \\
\text { (ns) }\end{array}$} \\
\hline & $\%$ & $50.0^{(1)}$ & $50.9^{(1)}$ & $42.6^{(1)}$ & & \\
\hline & $2000-$ & 8 & 18 & 29 & & \\
\hline & $\%$ & $28.6^{(1)}$ & $32.7^{(1)}$ & $28.7^{(1)}$ & & \\
\hline & $3000+$ & 6 & 9 & 29 & & \\
\hline & $\%$ & $21.4^{(1)}$ & $16.4^{(1)}$ & $28.7^{(1)}$ & & \\
\hline
\end{tabular}

(1) Indicates that the percentage has been calculated on the level of smoking status.

(2) Indicates that the percentage has been calculated on the gender level. 
To test Sub-hypothesis 2 of the fourth hypothesis, the Researcher used Crosstabs and Chi-square test. Table 9 shows the results of the tests.

The results of Table 9 confirmed that there is a relationship between the smokers' interest in buying a certain brand of cigarettes and some of the following demographic variables:

1) Age Groups: the Chi-square test value (Chi-square test $=31.448)$ confirms the statistical significance at the level of 0.01 with 8 degrees of freedom. Also, the frequency and percentage distribution in the previous table emphasized that there is a great interest in smoking local cigarettes in the Older Age groups. On the contrary, imported cigarettes are more popular among youth.

2) Gender: the Chi-square test value (Chi-square test $=6.546)$ confirms the statistical significance at the level of 0.01 with 2 degrees of freedom. Also the frequency and percentage distribution in the previous table emphasized that males are interested in buying imported brands of cigarettes. On the contrary, females have no interest in smoking a specific brand.

3) Education Level: the Chi-square test value (Chi-square test $=40.792)$ confirms the statistical significance at the level of 0.01 with 2 degrees of freedom. Also the frequency and percentage distribution in the previous table emphasized that highly educated individuals (University graduates, postgraduate studies holders) are highly interested in buying imported cigarettes. While, Basic and Intermediate Education graduates tend to buy local cigarettes.

4) Income Level: It was confirmed that there is no relationship between the different levels of income and being interested in buying a certain brand of cigarettes, where Chi-square test value did not come at a level that makes it significant at a minimum of 0.05 . This might explain a certain consumer behaviour in some developing countries where limited-income individuals consume high-cost foreign brands of cigarettes to reflect a better self-image or a higher social status, which is usually misleading.

\subsection{The Results of Testing Sub-hypothesis 3 of the Fourth Hypothesis}

"There is no relationship between reasons for smoking and some demographic characteristics of the smokers' sample (Age Groups, Gender, Education Level, Income Level)."

To test Sub-hypothesis 3 of the fourth hypothesis, the Researcher used the frequency and percentage distribution of Crossbars along with Chi-square test.

Results for the Relationship between Smoking Reasons and Age Groups

Table 10. Results for the relationship between smoking reasons and age groups

\begin{tabular}{|c|c|c|c|c|c|c|c|}
\hline Smoking Reasons & $\begin{array}{l}\text { Less than } \\
25 \text { years }\end{array}$ & $25-$ & $30-$ & $35-$ & $\begin{array}{l}\text { Over } 40 \\
\text { years }\end{array}$ & Statistical Test Value & $\begin{array}{l}\text { Level of } \\
\text { Significance }\end{array}$ \\
\hline A Relative & 4 & 2 & 6 & 3 & 6 & Kolmogorov-Smirnov $=$ & 0.965 \\
\hline$\%$ & 12.9 & 4.8 & 15.4 & 8.3 & 15.0 & $0.499^{(1)}$ & (ns) \\
\hline A Family Member & 1 & 4 & 6 & -- & 8 & Kolmogorov-Smirnov $=$ & 0.318 \\
\hline$\%$ & 3.2 & 9.5 & 15.4 & -- & 20.0 & 0.958 & (ns) \\
\hline Trying out & 8 & 20 & 17 & 12 & 16 & Chi-square test $=4.433$ & 0.351 \\
\hline$\%$ & 25.8 & 47.6 & 43.6 & 33.3 & 40.0 & $(\mathrm{~d} . \mathrm{f}=4)$ & (ns) \\
\hline A friend & 17 & 17 & 24 & 23 & 30 & Chi-square test $=10.876$ & 0.028 \\
\hline$\%$ & 54.8 & 40.5 & 61.5 & 63.9 & 75.0 & $(\mathrm{~d} . \mathrm{f}=4)$ & (sig. at 0.05$)$ \\
\hline
\end{tabular}

${ }^{(1)}$ Kolmogorov-Smirnov test is used as a result of the non-availability and inapplicability of Chi-square test application terms.

The results in Table 10 confirmed that there is a relationship between a specific smoking reason which is "A friend" and different Age Groups, where the Chi-square test value (Chi-square test $=10.87$ ) confirms the statistical significance at the level of 0.05 with 4 degrees of freedom. Also the frequency and percentage distribution of previous table emphasized that "A friend" is the basic reason behind buying and smoking cigarettes in the smokers' sample; this is true for different Age Groups, especially older groups: "30 -", "35 -" and "Over 40 years"; which means that the effect of friends and peer groups exists still even after adulthood. Thus, their role is not specific only to adolescence as some may believe.

These results did not correspond to relevant findings of other foreign studies. Samu et al. (2008) concluded that individuals are more affected by the fear appeals by friends or close circles than those by strangers. Lord (1994) 
also confirmed that threat-based appeals are more convincing when introduced by a relative or a close friend.

As for other reasons for smoking, the results confirmed that there is no relationship between the smokers' sample responses and different Age Groups as the test value (Chi-square test, Kolmogorov-Smirnov) did not reach the extent that makes it significant i.e. at least at a significance level of 0.05 .

Results for the Relationship between Smoking Reasons and Education Level

Table 11. Results for the relationship between smoking reasons and education level

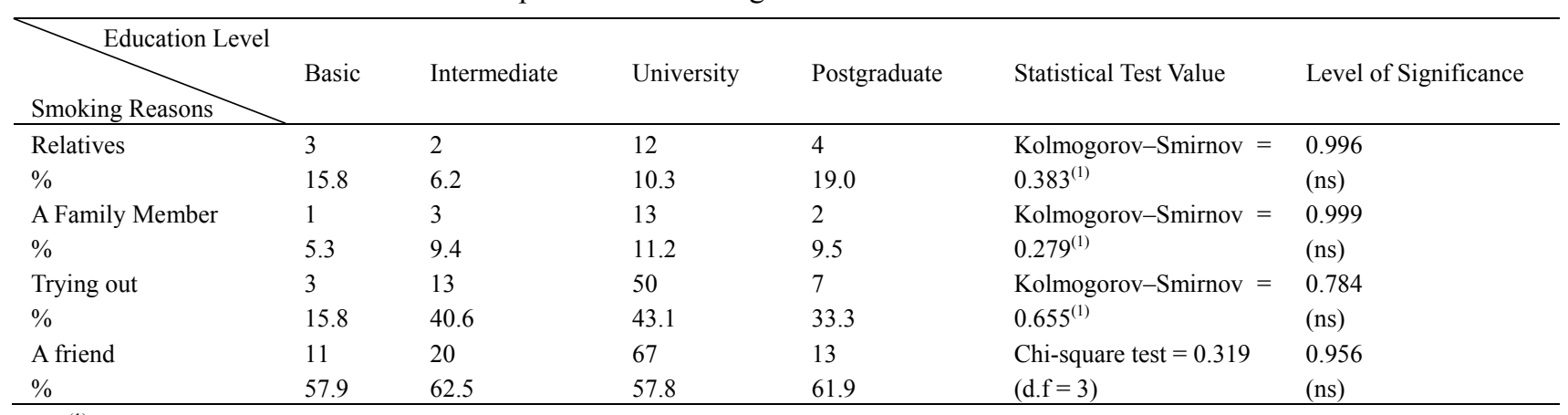

${ }^{(1)}$ Kolmogorov-Smirnov test is used as a result of the non-availability and inapplicability of Chi-square test application terms.

The results in Table 11 confirmed there is no relationship between smoking reasons and Education Level of the smokers' sample as the statistical test values (Chi-square test, Kolmogorov-Smirnov test) didn't reach the extent that makes them significant i.e. at least at a significance level of 0.05 .

Results for the Relationship between Smoking Reasons and Gender

Table 12. Results for the relationship between smoking reasons and gender (male/female)

\begin{tabular}{|c|c|c|c|c|}
\hline Smoking Reasons & Males & Females & $\begin{array}{l}\text { Chi-square Test } \\
\text { (d.f) }\end{array}$ & Level of Significance \\
\hline Relatives & 15 & 6 & 2.805 & 0.094 \\
\hline$\%$ & 9.5 & 20.0 & (1) & (ns) \\
\hline A Family Member & 15 & 4 & .409 & .522 \\
\hline$\%$ & 9.5 & 13.3 & (1) & (ns) \\
\hline Trying out & 66 & 7 & 3.609 & 0.057 \\
\hline$\%$ & 41.8 & 23.3 & (1) & (ns) \\
\hline A friend & 99 & 12 & 5.353 & 0.021 \\
\hline$\%$ & 62.7 & 40.0 & (1) & $(\mathrm{ns})$ \\
\hline
\end{tabular}

The results in Table 12 confirmed the existence of a relationship between a specific smoking reason which is "A friend" and gender as the Chi-square test (Chi-square test $=2.353$ ) confirms the statistical significance at the level of 0.05 with 1 degree of freedom. The frequency and percentage distribution in Table 12 also emphasized that the reason "A friend" is the main reason for smoking for males; it clearly appeared in about $63 \%$ of the total male sample; while with females, it appeared in only $40 \%$ of the sample.

This might be particularly obvious in the culture and behaviour patterns in certain Eastern Societies where the role of friends among males has evident effects due to the freedom characterizing their relationships, with gatherings that are usually highly recurring and unlimited by time or place. On the other hand, such a huge effect of friendship roles is not as apparent in the female community which is mostly bound by certain limitations that allow them fewer meetings and limited time and space options. In these circumstances, female smoking can be viewed as a personal and inner desire to break social restrictions and feel some sense of freedom.

As for the other reasons, the results confirmed that there is no relationship between smokers' sample's response to those reasons as associated with gender because the test values (Chi-square test) did not reach the extent that makes them significant i.e. at least at a significance level of 0.05 . 


\section{Results for the Relationship between Smoking Reasons and Income Level}

Table 13. Results for the relationship between smoking reasons and income level

\begin{tabular}{|c|c|c|c|c|c|c|}
\hline Smoking Reasons & Less than 2000 & $2000-$ & $3000-$ & $4000+$ & Statistical Test Value & $\begin{array}{l}\text { Level of } \\
\text { Significance }\end{array}$ \\
\hline Relatives & 9 & 4 & 6 & 2 & \multirow{2}{*}{ Kolmogorov-Smirnov $=0.383^{(1)}$} & .996 \\
\hline$\%$ & 10.1 & 7.3 & 28.6 & 8.7 & & (ns) \\
\hline A Family Member & 3 & 10 & 6 & -- & \multirow{2}{*}{ Kolmogorov-Smirnov $=0.383^{(1)}$} & .998 \\
\hline$\%$ & 3.4 & 18.2 & 28.6 & -- & & (ns) \\
\hline Trying out & 31 & 19 & 15 & 8 & Chi-square $=10.578$ & 0.0140 \\
\hline$\%$ & 34.8 & 34.5 & 71.4 & 34.8 & (3) & (sig. at 0.05 ) \\
\hline A friend & 48 & 31 & 13 & 19 & Chi-square $=6.477$ & 0.091 \\
\hline$\%$ & 53.9 & 56.4 & 61.9 & 82.6 & (3) & (ns) \\
\hline
\end{tabular}

${ }^{(1)}$ Kolmogorov-Smirnov test is used as a result of the non-availability and inapplicability of Chi-square test application terms.

The results of Table 13 confirmed that there is a relationship between smoking reasons, represented specifically in the reason "Trying out", and Income Levels as the Chi-square test value (Chi-square test $=10.578$ ) confirms the statistical significance at the level of 0.05 with 3 degrees of freedom. Also the frequency and percentage distribution in Table 13 emphasized that "Trying out" is one of the most important reasons that explain smoking in relation to different income levels, especially the income levels of "3000 -" and "Less than 4000"

A probable explanation for these findings is that, at the time this research was conducted, the above-mentioned income levels were the financial threshold of the Middle Social Class in Egypt. The individuals of this class have the financial ability and usually the desire to try smoking, which is viewed as a new experience; an ability which usually does not present itself to those of the lower social classes who are more concerned with basic spending priorities. Other individuals of higher financial classes usually pass that trying phase and either lose interest in smoking or choose to divert their financial spending to more productive pursuits.

As for the other reasons, the results confirmed that there is no relationship between different levels of income and any of them as the results have confirmed that test values (Chi-square test, Kolmogorov-Smirnov test) did not reach the extent that makes them significant i.e. at least at a significance level of 0.05 .

\subsection{The Results of Testing Sub-hypothesis 4 of the Fourth Hypothesis}

"There is no relationship between reading warning messages on cigarettes packs and certain demographic characteristics of the smokers' sample (Age Groups, Gender, Education Level, Income Level)."

Table 14. Results for the relationship between certain demographic variables and reading warning messages on cigarette packs

\begin{tabular}{|c|c|c|c|c|c|}
\hline \multicolumn{6}{|c|}{ Certain Demographic Variables } \\
\hline Age Groups & $\begin{array}{l}\text { Less than } 25 \text { yrs } \\
\% \\
25- \\
\% \\
30- \\
\% \\
35- \\
\% \\
40+\text { years } \\
\% \\
\end{array}$ & $\begin{array}{l}31 \\
17.6 \\
42 \\
23.9 \\
35 \\
19.9 \\
33 \\
18.8 \\
35 \\
19.9 \\
\end{array}$ & $\begin{array}{l}-- \\
-- \\
-- \\
-- \\
4 \\
33.3 \\
3 \\
25.00 \\
5 \\
41.7 \\
\end{array}$ & Kolmogorov-Smirnov $=1.390$ & $\begin{array}{l}0.042 \\
\text { (sig. at } 0.05 \text { ) }\end{array}$ \\
\hline Gender & $\begin{array}{l}\text { Males } \\
\% \\
\text { Females } \\
\%\end{array}$ & $\begin{array}{l}151 \\
95.6 \\
25 \\
83.3\end{array}$ & $\begin{array}{l}7 \\
4.4 \\
5 \\
16.7\end{array}$ & $\begin{array}{l}\text { Chi-square test }=6.317 \\
(\text { d.f }=1)\end{array}$ & $\begin{array}{l}0.012 \\
\text { (sig. at } 0.05 \text { ) }\end{array}$ \\
\hline
\end{tabular}




\begin{tabular}{|c|c|c|c|c|c|}
\hline \multirow{8}{*}{ Education Level } & Basic & 15 & 4 & \multirow{8}{*}{ Kolmogorov-Smirnov $=0.832$} & \multirow{8}{*}{$\begin{array}{l}0.494 \\
\text { (ns) }\end{array}$} \\
\hline & $\%$ & 8.5 & 33.3 & & \\
\hline & Intermediate & 31 & 1 & & \\
\hline & $\%$ & 17.6 & 8.3 & & \\
\hline & University & 109 & 7 & & \\
\hline & $\%$ & 61.9 & 58.3 & & \\
\hline & Postgraduate & 21 & -- & & \\
\hline & $\%$ & 11.9 & -- & & \\
\hline \multirow{8}{*}{ Income Level } & Less than 2000 & 82 & 7 & \multirow{8}{*}{ Kolmogorov-Smirnov $=0.394$} & \multirow{8}{*}{$\begin{array}{l}0.996 \\
(\mathrm{~ns})\end{array}$} \\
\hline & $\%$ & 46.6 & 58.3 & & \\
\hline & $2000-$ & 53 & 2 & & \\
\hline & $\%$ & 30.1 & 16.7 & & \\
\hline & $3000-$ & 19 & 2 & & \\
\hline & $\%$ & 10.8 & 16.7 & & \\
\hline & $4000+$ & 22 & 1 & & \\
\hline & $\%$ & 12.5 & 8.3 & & \\
\hline
\end{tabular}

To test Sub-hypothesis 4 of the fourth hypothesis, the Researcher used the frequency and percentage distribution via the frequency table, along with Chi-square test. Table 14 shows the results of the tests. The results of the table confirmed the existence of significant differences according to the frequency and percentage distribution in certain demographic variables associated with reading warning messages as follows:

1) Age Groups: the value of the Kolmogorov-Smirnov test (Kolmogorov-Smirnov $=1.390)$ confirms the statistical significance at a level of 0.05 . This was confirmed by the frequency and percentage distribution for the responses of the research sample where the results confirmed that there is a great interest in reading warning messages by the younger Age Groups: "Less than 25 years old and " 25 years to less than 30 years", while the degree of interest is not the same with older Age Groups (See Recommendations). The reason behind this drop in interest is probably their familiarity with these warning messages, which renders the fear and threat-based appeals about the negative effects of smoking very monotonous. Also, the delay of these related health issues to late stages of life (after 60 usually) voids the warnings of their effectiveness (The language of discourse that target older Age Groups must be renewed and warning messages must be rephrased in a studied and informed manner that touches upon particular fears and threats which might haunt older people.

2) Gender: the Chi-square test value (Chi-square test $=6.317)$ confirms the statistical significance at a level of 0.05 . The frequency and percentage distribution confirms that males are mostly interested in reading these warning messages than females. That might be a result of the fact that women are usually driven towards smoking by a desire to have an emotional outlet or break free from social conventions, unlike men who are usually driven by peer pressure or the desire to try smoking as an experience. As for the other demographic variables of each Education Level and Income Level, the results confirm that there are no differences in terms of frequency and percentage distribution. This has been emphasized by the statistical test value of Kolmogorov-Smirnov test, which did not reach the extent that makes it significant i.e. the level of at least 0.05 .

According to the above-mentioned, we can accept Sub-hypothesis 4 of the Fourth Hypothesis in terms of the results for Education Level and Income Level, and refuse them on terms of Gender and Age Groups.

\subsection{The Results of Testing Sub-hypothesis 5 of the Fourth Hypothesis:}

"There are no statistically significant differences regarding the different effects of some warning messages written on cigarette packs when measured against certain demographic characteristics of the smokers' sample (Age Groups, Gender, Education Level, Income Level)."

To test Sub-hypothesis 5 of the fourth hypothesis, the Researcher used descriptive statistics of data, represented in the arithmetic mean; Kruskal-Wallis test; and Mann-Whitney U test. And these are the results. 


\section{The Impact of Warning messages on Cigarette Packs according to Age Groups}

Table 15. The different effects of cigarette packs' warnings according to age groups of the research sample

\begin{tabular}{|c|c|c|c|c|c|c|c|c|c|c|}
\hline \multirow[b]{2}{*}{ Phrases } & \multirow[b]{2}{*}{ Age Distribution } & \multicolumn{2}{|c|}{ Descriptive Statistics } & \multicolumn{2}{|c|}{$\begin{array}{l}\text { Kruskal-Wallis Test } \\
\text { Result }\end{array}$} & \multicolumn{5}{|c|}{ Mann-Whitney- U Test Result } \\
\hline & & $\begin{array}{l}\text { Mean } \\
\text { Ranks }\end{array}$ & $\begin{array}{l}\text { Arithmetic } \\
\text { Mean }\end{array}$ & $\begin{array}{l}\text { Chi-square } \\
\text { test } \\
(\mathrm{d} . \mathrm{f}=4)\end{array}$ & $\begin{array}{l}\text { Level of } \\
\text { Sig. }\end{array}$ & $\begin{array}{l}\text { Less } \\
\text { than } \\
25 \\
\end{array}$ & -25 & -30 & -35 & $40+$ \\
\hline \multirow{5}{*}{$\begin{array}{l}1 \text { - Smoking is } \\
\text { very harmful } \\
\text { to health }\end{array}$} & Less than 25 & 81.48 & 2.29 & \multirow{5}{*}{4.461} & & -- & & \multirow{5}{*}{--} & \multirow{5}{*}{--} & \\
\hline & $25-$ & 85.71 & 2.38 & & & & -- & & & \\
\hline & $30-$ & 84.69 & 2.40 & & 0.326 & & & & & \\
\hline & $35-$ & 79.60 & 2.20 & & (ns) & & & & & \\
\hline & $40+$ & 102.09 & 2.77 & & & & & & & -- \\
\hline \multirow{5}{*}{$\begin{array}{l}\text { 2- Smoking } \\
\text { causes } \\
\text { cardiovascular } \\
\text { diseases }\end{array}$} & Less than 25 & 102.73 & 2.61 & \multirow{5}{*}{13.990} & \multirow{5}{*}{$\begin{array}{l}0.007 \\
\text { (sig. at } \\
0.05)\end{array}$} & -- & ${ }^{*} 2.930$ & 1.867 & 1.297 & 0.178 \\
\hline & $25-$ & 66.39 & 1.86 & & & & -- & 1.676 & *2.313 & *2.870 \\
\hline & $30-$ & 82.46 & 2.17 & & & & & -- & 0.588 & 1.69 \\
\hline & $35-$ & 89.50 & 2.33 & & & & & & -- & 1.018 \\
\hline & $40+$ & 100.20 & 2.57 & & & & & & & -- \\
\hline \multirow{5}{*}{$\begin{array}{l}\text { 3-Smoking is } \\
\text { harmful to } \\
\text { children }\end{array}$} & Less than 25 & 74.37 & 1.94 & \multirow{5}{*}{8.626} & & -- & & & & \\
\hline & $25-$ & 101.38 & 2.38 & & & & -- & & & \\
\hline & $30-$ & 91.60 & 2.23 & & 0.071 & & & -- & & \\
\hline & $35-$ & 76.80 & 2.03 & & (ns) & & & & -- & \\
\hline & $40+$ & 85.07 & 2.20 & & & & & & & -- \\
\hline \multirow{5}{*}{$\begin{array}{l}\text { 4- Keep your } \\
\text { children away } \\
\text { from smoking }\end{array}$} & Less than 25 & 97.81 & 2.61 & \multirow{5}{*}{12.435} & \multirow{5}{*}{$\begin{array}{l}0.014 \\
\text { (sig. at } \\
0.05)\end{array}$} & -- & 0.178 & 0.946 & 1.242 & ${ }^{*} 2.659$ \\
\hline & $25-$ & 100.79 & 2.64 & & & & -- & 1.348 & 1.555 & ${ }^{*} 3.330$ \\
\hline & $30-$ & 85.70 & 2.34 & & & & & -- & 0.192 & 1.715 \\
\hline & $35-$ & 83.47 & 2.23 & & & & & & -- & 1.675 \\
\hline & $40+$ & 65.21 & 1.86 & & & & & & & -- \\
\hline
\end{tabular}

* Indicates to the significance of Mann-Whitney- U Test.

The results of Table 15 confirmed that there are statistically significant differences between the impacts of the following phrases written on cigarette pack according to Age Groups:

Smoking causes cardiovascular diseases: the value of Kruskal-Wallis test (Chi-square test $=13.990)$ confirms the statistical significance at a level of 0.01 with 4 degrees of freedom. The Mann-Whitney test showed that these differences are found between the responses of the research sample in the following Age Groups: " 25 to less than 30 " with each of "less than 25 ", "From 35 to less than 40 " and "40 years and more". The descriptive statistics confirm that these differences are in favor of the Age Group " 25 to less than 30" responses.

Keep your children away from smoking: the value of the Kruskal-Wallis test (Chi-square test $=12.435)$ confirmed the statistical significance at a level of 0.05 . The Mann-Whitney test showed that these differences are found between the responses of the research sample in the following Age Groups: " 40 years and more" with each of "Less than 25", "25 years old" and "Less than 30". The descriptive statistics confirm that these differences are in favor of the Age Group "40 years and more".

Therefore, the previous observations can be explained as follows: the phrase "Smoking causes cardiovascular diseases" affected almost all the Age Groups of the sample, but it did not have the same positive effect on the Age Group "From 25 to less than 35". This might be because in this young age, individuals do not usually pay much attention to health in general as older people do. At this stage, an individual seeks accomplishing other needs (Maslow's Hierarchy of Needs) like building a family and having children, which in fact corresponds to what the results have shown in that they respond better to the phrase "Keep your children away from smoking". Older people at 40 years old and more have already accomplished those social needs and they move to other needs like self-esteem and self-actualization which means that they pay more attention to cigarette brand choice (See Table 9).

As for the responses of research sample to other phrases: "Smoking is very harmful to health" and "Smoking is harmful to children", the results showed no statistically significant differences, where the Chi-square values of the Kruskal-Wallis test did not reach the extent that makes it significant i.e. the level of at least 0.05. Meanwhile, all age groups agreed on the efficacy of the previous two phrases, especially "Smoking is harmful to children". These 
results are consistent with the results of Latour et al. (2003) confirming that individuals who have children respond better to appeals based on health threats. Tanner et al. (1991) also confirmed that positive recommendations that affect the closer circles in the smoker's life are more persuasive.

\section{The Impact of Warning Messages on Cigarette Packs According to Education Level}

Table 16. The different effects of cigarette packs' warnings according to education level of the research sample

\begin{tabular}{|c|c|c|c|c|c|c|c|c|c|}
\hline \multirow[b]{2}{*}{ Phrases } & \multirow[b]{2}{*}{$\begin{array}{l}\text { Education } \\
\text { Level }\end{array}$} & \multicolumn{2}{|c|}{ Descriptive Statistics } & \multicolumn{2}{|c|}{$\begin{array}{l}\text { Kruskal-Wallis Test } \\
\text { Result }\end{array}$} & \multicolumn{4}{|c|}{ Mann-Whitney- U Test Result } \\
\hline & & $\begin{array}{l}\text { Mean } \\
\text { Ranks }\end{array}$ & $\begin{array}{l}\text { Arithmetic } \\
\text { Mean }\end{array}$ & $\begin{array}{l}\text { Chi-square } \\
\text { test } \\
(\text { d.f }=4)\end{array}$ & $\begin{array}{l}\text { Level } \\
\text { of sig. }\end{array}$ & Basic & Intermediate & University & Postgraduate \\
\hline \multirow{4}{*}{$\begin{array}{l}1 \text { - Smoking is } \\
\text { very harmful to } \\
\text { health }\end{array}$} & Basic & 42.0 & 1.33 & \multirow{4}{*}{$\begin{array}{l}11.482 \\
(3)\end{array}$} & \multirow{4}{*}{$\begin{array}{l}0.009 \\
\text { (sig. at } \\
0.05)\end{array}$} & \multirow[t]{4}{*}{--} & \multirow{4}{*}{$\begin{array}{l}3.638^{*} \\
--\end{array}$} & \multirow{4}{*}{$\begin{array}{l}3.016^{*} \\
.068 \\
--\end{array}$} & $3.215^{*}$ \\
\hline & Intermediate & 92.71 & 2.52 & & & & & & .715 \\
\hline & University & 90.58 & 2.52 & & & & & & .467 \\
\hline & Postgraduate & 85.71 & 2.33 & & & & & & -- \\
\hline \multirow{4}{*}{$\begin{array}{l}\text { 2- Smoking } \\
\text { causes } \\
\text { cardiovascular } \\
\text { diseases }\end{array}$} & Basic & 104.58 & 2.67 & \multirow{4}{*}{$\begin{array}{l}4.884 \\
(3)\end{array}$} & \multirow{4}{*}{$\begin{array}{l}0.180 \\
(\mathrm{~ns})\end{array}$} & -- & \multirow{4}{*}{--} & & \\
\hline & Intermediate & 85.05 & 2.26 & & & & & & \\
\hline & University & 89.14 & 2.32 & & & & & -- & \\
\hline & Postgraduate & 68.71 & 1.90 & & & & & & -- \\
\hline \multirow{4}{*}{$\begin{array}{l}\text { 3-Smoking is } \\
\text { harmful to } \\
\text { children }\end{array}$} & Basic & 78.50 & 2 & \multirow{4}{*}{$\begin{array}{l}1.873 \\
(3)\end{array}$} & \multirow{4}{*}{$\begin{array}{l}0.599 \\
(\mathrm{~ns})\end{array}$} & -- & \multirow{4}{*}{--} & & \\
\hline & Intermediate & 94.76 & 2.35 & & & & & & \\
\hline & University & 87.12 & 2.17 & & & & & -- & \\
\hline & Postgraduate & 79.79 & 2.05 & & & & & & -- \\
\hline \multirow{4}{*}{$\begin{array}{l}\text { 4-Keep your } \\
\text { children away } \\
\text { from smoking }\end{array}$} & Basic & 113.96 & 3 & \multirow{4}{*}{$\begin{array}{l}6.711 \\
(3)\end{array}$} & \multirow{4}{*}{$\begin{array}{l}0.082 \\
(\mathrm{~ns})\end{array}$} & -- & \multirow{4}{*}{--} & & \\
\hline & Intermediate & 73.05 & 2 & & & & & & \\
\hline & University & 86.89 & 2.35 & & & & & -- & \\
\hline & Postgraduate & 92.79 & 2.48 & & & & & & -- \\
\hline
\end{tabular}

* Indicates to the significance of Mann-Whitney- U Test.

The results of Table 16 confirmed that there are statistically significant differences between the research sample responses at the level of results of "smoking is very harmful to health" phrase, where the Kruskal-Wallis test value (Chi-square test $=11.482)$ confirms the statistical significance at a level of 0.01 .

Conducting the Mann-Whitney test between each two levels, it was evident that these differences exist between the Basic Education level and all the other education levels. The descriptive statistics confirm that these differences are in favor of the Basic Education level. Although self-evident, this message is written on cigarette packs. It is still considered the main warning message that the Egyptian government and the Ministry of Health require companies to write on cigarette packs despite the fact that its effect and persuasiveness are limited to the sample participants with Basic Education and very low knowledge levels.

As for the other phrases, the results confirmed that there are no statistically significant differences among the different levels of education, which is emphasized by the Kruskal-Wallis test value as well as the descriptive statistics in the results.

\section{The Impact of Warning Messages on Cigarette Pack According to Gender}

Table 17. The different effects of cigarette packs' warnings according to gender of the research sample

\begin{tabular}{|c|c|c|c|c|c|}
\hline \multirow{2}{*}{ Phrase } & \multirow{2}{*}{ Gender } & \multicolumn{2}{|c|}{ Descriptive statistics } & \multirow{2}{*}{ Test Value of $Z$} & \multirow{2}{*}{ Level of Significance } \\
\hline & & Mean Ranks & Mean Values & & \\
\hline \multirow{2}{*}{ 1- Smoking is very harmful to health } & Males & 88.0 & 2.43 & \multirow{2}{*}{0.665} & 0.506 \\
\hline & Females & 81.06 & 2.32 & & (ns) \\
\hline \multirow{2}{*}{ 2- Smoking causes cardiovascular diseases } & Males & 83.88 & 2.22 & \multirow{2}{*}{2.075} & 0.038 \\
\hline & Females & 105.50 & 2.64 & & (sig. at 0.05 ) \\
\hline \multirow{2}{*}{ 3- Smoking is harmful to children } & Males & 86.77 & 2.17 & \multirow{2}{*}{0.163} & 0.871 \\
\hline & Females & 88.36 & 2.20 & & (ns) \\
\hline \multirow{2}{*}{ 4-Keep your children away from smoking } & Males & 83.97 & 2.26 & \multirow{2}{*}{2.142} & 0.032 \\
\hline & Females & 106.02 & 2.84 & & (sig. at 0.05 ) \\
\hline
\end{tabular}


The results of Table 17 confirmed that there are statistically significant differences according to Gender (Males, Females) for the following two statements:

Smoking causes cardiovascular diseases: the value of Mann-Whitney test $(Z=2.075)$ confirms the statistical significance at a level of 0.05 . The descriptive statistics confirm that males are more affected by this phrase than females. Warning messages that draw upon threat can elicit a fear for a man's own perceived image and personal power, which can have a positive effect similar to what a woman may experience with a warning message that points to threats or dangers to her beauty or skin.

Keep your children away from smoking: the value of the Mann-Whitney test $(\mathrm{Z}=2.142)$ confirms the statistical significance at a level of 0.05 . The descriptive statistics confirm how males are more affected with this phrase than females. This could be explained by the fact that men are more aware of how they can inflect negative effect of smoking on their children, which drives them to smoke in open places or away from children. Females tend to smoke inside where children might exist because they are mostly the primary care-givers and they usually accompany children most of the time. Some females continue smoking during pregnancy and breastfeeding against doctors' advice.

As for the results of both phrases "smoking is very harmful to health" and "smoking is harmful to children", they confirm that there is no statistically significant differences between males and females, where the Mann-Whitney test values did not reach the extent that makes it significant i.e. the level of at least 0.05 .

From the above, we can conclude that males are more interested than females in reading the two warning statements: "smoking causes cardiovascular diseases" and "keep the kids away from smoking", which was evident in the mean ranks results in Table 17; this may be due to the fact that males have more exposure to these warning phrases than females as shown in comparing the number of smoked cigarettes per day between males and females (See Table 8a: Results of Differences in the Average Daily Number of Cigarettes according to certain Demographic Variables in the Smokers Sample - Sub-hypothesis 1 of Hypothesis 4). This contradicts the results of Lennon et al. 2010 study which concluded that women are more apt to be convinced by fear-eliciting warning messages than males.

The Impact of Warning Messages on Cigarette Pack According to Income Levels

Table 18. The different effects of cigarette packs' warnings according to income levels of the research sample

\begin{tabular}{|c|c|c|c|c|c|c|c|c|c|}
\hline \multirow[b]{2}{*}{ Phrases } & \multirow[b]{2}{*}{ Income Level } & \multicolumn{2}{|c|}{$\begin{array}{l}\text { Descriptive } \\
\text { Statistics }\end{array}$} & \multicolumn{2}{|c|}{$\begin{array}{l}\text { Kruskal-Wallis Test } \\
\text { Result }\end{array}$} & \multicolumn{4}{|c|}{ Mann-Whitney U Test Result } \\
\hline & & $\begin{array}{l}\text { Mean } \\
\text { Time }\end{array}$ & $\begin{array}{l}\text { Mean } \\
\text { values }\end{array}$ & $\begin{array}{l}\text { Chi-square } \\
\text { Test (d.f) }\end{array}$ & $\begin{array}{l}\text { Level } \\
\text { of Sig. }\end{array}$ & $\begin{array}{l}\text { Less } \\
\text { than } \\
2000\end{array}$ & -2000 & -3000 & $\begin{array}{l}\text { Over } \\
4000\end{array}$ \\
\hline $\begin{array}{l}\text { 1- Smoking is } \\
\text { very harmful } \\
\text { to health }\end{array}$ & $\begin{array}{l}\text { Less than } 2000 \\
-2000 \\
-3000 \\
+4000\end{array}$ & $\begin{array}{l}77.98 \\
86.12 \\
91.91 \\
118.52\end{array}$ & $\begin{array}{l}2.20 \\
2.40 \\
2.53 \\
3.18\end{array}$ & $\begin{array}{l}12.409 \\
(3)\end{array}$ & $\begin{array}{l}0.006 \\
\text { (sig. at } \\
0.01 \text { ) }\end{array}$ & -- & $\begin{array}{l}0.987 \\
--\end{array}$ & $\begin{array}{l}1.141 \\
.425 \\
--\end{array}$ & $\begin{array}{l}3.425^{*} \\
2.703^{*} \\
1.853 \\
--\end{array}$ \\
\hline $\begin{array}{l}\text { 2- Smoking } \\
\text { causes } \\
\text { cardiovascular } \\
\text { diseases }\end{array}$ & $\begin{array}{l}\text { Less than } 2000 \\
-2000 \\
-3000 \\
+4000 \\
\text { Over } 4000\end{array}$ & $\begin{array}{l}73.42 \\
90.81 \\
114.12 \\
106.86 \\
50.75 \\
\end{array}$ & $\begin{array}{l}2 \\
2.36 \\
2.88 \\
2.68 \\
1.50 \\
\end{array}$ & $\begin{array}{l}15.875 \\
(3)\end{array}$ & $\begin{array}{l}0.001 \\
\text { (sig. at } \\
0.01 \text { ) }\end{array}$ & - & $\begin{array}{l}2.145^{*} \\
--\end{array}$ & $\begin{array}{l}2.928^{*} \\
1.877 \\
--\end{array}$ & $\begin{array}{l}2.936^{*} \\
1.434 \\
0.369 \\
--\end{array}$ \\
\hline $\begin{array}{l}\text { 3- Smoking is } \\
\text { harmful to } \\
\text { children }\end{array}$ & $\begin{array}{l}\text { Less than } 2000 \\
-2000 \\
-3000 \\
+4000\end{array}$ & $\begin{array}{l}92.89 \\
93.25 \\
66.47 \\
66.14 \\
\end{array}$ & $\begin{array}{l}2.25 \\
2.32 \\
1.82 \\
1.82 \\
\end{array}$ & $\begin{array}{l}10.582 \\
(3)\end{array}$ & $\begin{array}{l}0.014 \\
\text { (sig. at } \\
0.05)\end{array}$ & -- & $\begin{array}{l}0.196 \\
--\end{array}$ & $\begin{array}{l}2.359 * \\
1.872 \\
--\end{array}$ & $\begin{array}{l}2.661 * \\
2.101^{*} \\
.966 \\
--\end{array}$ \\
\hline $\begin{array}{l}\text { 4- Keep your } \\
\text { children away } \\
\text { from smoking }\end{array}$ & $\begin{array}{l}\text { Less than } 2000 \\
-2000 \\
-3000 \\
\text { Over } 4000\end{array}$ & $\begin{array}{l}96.21 \\
95.73 \\
62.82 \\
50.75\end{array}$ & $\begin{array}{l}2.54 \\
2.58 \\
1.76 \\
1.50\end{array}$ & $\begin{array}{l}21.596 \\
(3)\end{array}$ & $\begin{array}{l}0.000 \\
\text { (sig. at } \\
0.01 \text { ) }\end{array}$ & -- & $\begin{array}{l}0.100 \\
--\end{array}$ & $\begin{array}{l}2.736^{*} \\
2.321^{*} \\
--\end{array}$ & $\begin{array}{l}4.104^{*} \\
3.431^{*} \\
0.326 \\
--\end{array}$ \\
\hline
\end{tabular}

* Indicates to the significance of Mann-Whitney- U Test.

The results of Table 18 confirmed that there are statistically significant differences, according to the different levels of income, for all the following phrases: 
Smoking is very harmful to health: the Kruskal-Wallis test value (Chi-square test $=12.409)$ confirms the significance at a level of 0.01 with 3 degrees of freedom. The Mann-Whitney test showed that these differences are between the high-income level "4000 and more" and each of these Income Levels: "Less than 2000" "2000 -" and "Less than 3000". The descriptive statistics confirm that these differences are in favor of the low-income levels: "Less than 2000" and "2000 to less than 3000" since the phrase is self-evident as shown in the "Education Level" results (See Table 16) and most of the individuals at these income levels usually have lower levels of education.

Smoking causes cardiovascular diseases: the Kruskal-Wallis test value (Chi-square test $=15.875)$ confirms the statistical significance at a level of 0.01 with 3 degrees of freedom. The Mann-Whitney test shows that these differences are between the income level "Less than 2000" and all the other income levels. The descriptive statistics confirmed that these differences are in favor of the low-income level "Less than 2000". The individuals at this income level usually develop a fear of heart diseases and smoking issues because of the high treatment costs. When the warning messages draw upon fear, they usually achieve higher responses.

Smoking is very harmful to children: the Kruskal-Wallis test value (Chi-square test $=10.582$ ) confirms the statistical significance at a level of 0.01 with 3 degrees of freedom. The Mann-Whitney test shows that these differences are between the high-income level " 4000 and more" and the two low-income levels of "Less than 2000 " and "2000 to less than 3000"; in addition to differences between the high-income level "3000 to less than 4000" and the low-income level "Less than 2000". The descriptive statistics confirm that these differences are in favor of the high-income levels "3000 to less than 4000" and "4000 and more". Individuals at this income level enjoy relatively higher living standards, which means that they pay more attention to their children's health.

Keep your children away from smoking: the Kruskal-Wallis test value (Chi-square test $=21.596)$ confirms the statistical significance at a level of 0.01 with 3 degrees of freedom. The Mann-Whitney test shows that these differences are between the two high-income levels of "3000 to less than 4000 " and " 4000 and more" on one side, and the low-income levels "Less than 2000" and "2000 to less than 3000" on the other. The descriptive statistics confirm that these differences are in favor of these two high-income levels. This corresponds to the previous results above. This phrase is the most effective with high-income levels even in comparison with the previous phrase.

From the above-mentioned, we can partially accept Sub-hypothesis 5 in the Fourth Hypothesis. And from the sum of all the previous results, we can partially accept the Fourth Hypothesis as a whole.

\section{Testing the Fifth Hypothesis}

$\mathrm{H}_{5}$ There is no relationship between health problems that smokers suffer as a result of smoking and the decision to continue smoking whilst being fully aware of these problems.

To test the fifth hypothesis $\left(\mathrm{H}_{5}\right)$, the Researcher used Crosstabs along with Chi-square test in order to examine the relationship between variables.

Table 19. Results for the relationship between suffering certain diseases due to smoking and deciding to continue smoking or attempting to quit

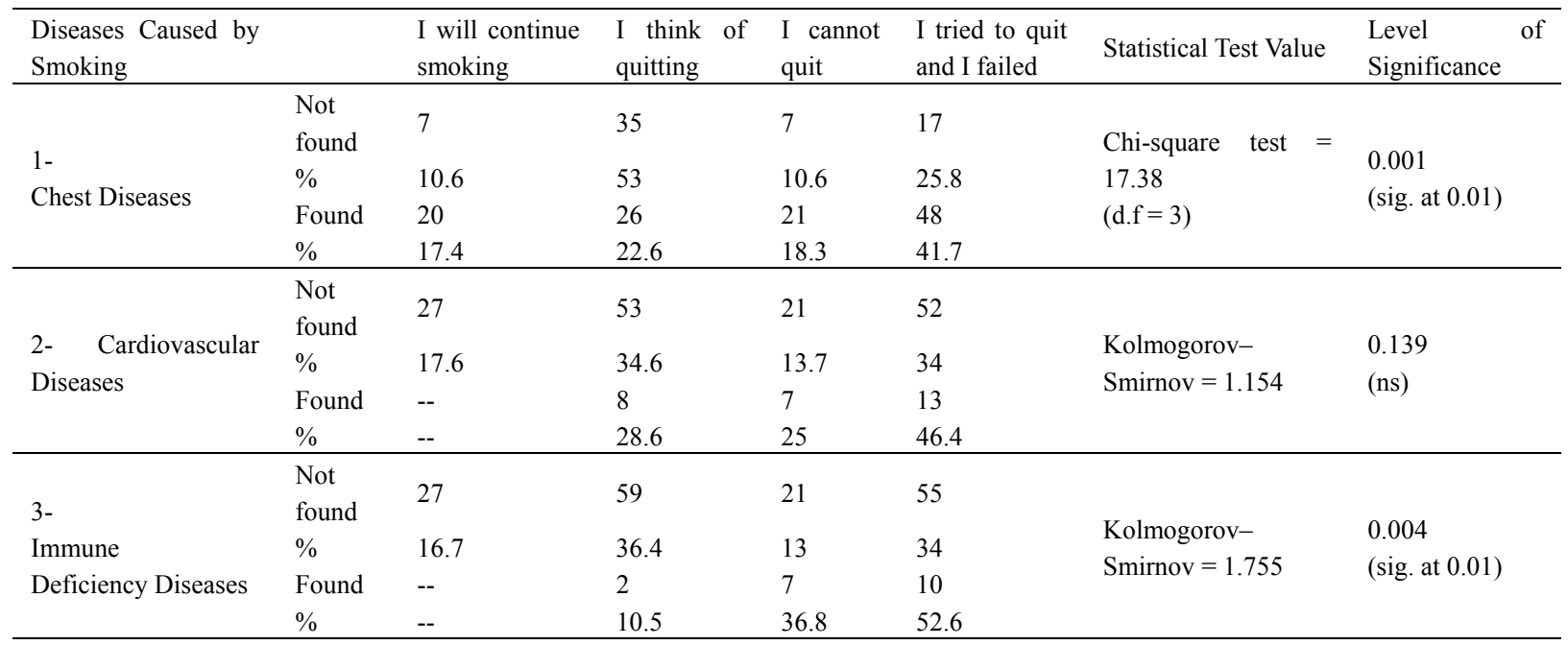


The results of Table 19 confirmed that the relationship between suffering from certain diseases as a result of smoking and the decision to continue smoking or attempting to quit:

Chest Diseases: the Chi-square test value (Chi-square test $=17.38)$ confirms the statistical significance at a level of 0.01. As we find in the percentage distribution, these diseases have a significant effect in inducing the following responses: "Attempting to quit" and "Considering quitting", but not so much in inducing these responses: "Continuing smoking" and "Inability to quit".

Immune Deficiency Diseases: the Kolmogorov-Smirnov test value (Kolmogorov-Smirnov $=1.755)$ confirms the statistical significance at a level of 0.01 . But generally, we find that Immune Deficiency Diseases do not usually occur as a direct result of smoking, but they might be a result of other smoking-inflicted diseases. Nevertheless, we find that "Attempting to quit" is the most recurrent, followed by "Inability to quit smoking" as well as "Considering quitting", which has a limited occurrence level. This reflects that there isn't any continuity in the decisions taken.

As for suffering Cardiovascular Diseases, the results confirmed that there is no relationship between suffering from these diseases and the decision to continue smoking or attempting to quit, as the value of KolmogorovSmirnov test did not reach the minimum extent that makes it significant i.e. the level of at least 0.05 .

From the above, we can partially accept the Fifth Hypothesis, but we lean towards rejecting it.

\section{Conclusion}

\subsection{First: Results Related to the Characteristics of Smokers}

1) Higher education levels (University degree, post-graduate studies) tip the balance of behaviour in favor of not smoking; that's why individuals of these levels have the lowest smoking rate measured by the number of smoked cigarettes.

2) Judging by the demographical characteristics of the research sample, high income smokers are usually older. And since it is usually the one age group that is most vulnerable to health problems, this might be the reason why fear of health issues came second in the list of reasons for quitting for that particular income group.

3) The primary reason for smoking is friends and that's usually among males. The second is the desire to try which is more evident in the middle income levels of " 3000 " and "Less than 4000".

4) Young males are interested in smoking foreign cigarette brands and the opposite is true for older males; those prefer smoking local brands. Women, on the other hand, have no particular preference when it comes to "local vs. foreign" brands.

5) Smoking is affected by both: Education Level and Income Level; and this relationship is inverse i.e. higher education and income levels entail total rejection of smoking or at least serious attempts to quit.

\subsection{Second: Studying the Efficiency of Warning Messages}

1) There is an evident relationship between reading the warning messages and the smoking status of an individual; and $88 \%$ of those who are interested in reading warning messages are young male smokers.

2) The effect size of warning messages written on cigarette packs differs according to certain demographic elements. The phrase "Smoking is very harmful to health" mostly affects individuals with primary education level and individuals with low income levels: "Less than 2000", "2000" and "Less than 3000".

3) The phrase "Smoking causes cardiovascular diseases" mostly affects young male smokers of low income levels_-"Less than 2000".

4) The phrase "Smoking is very harmful to children" affect males with high income.

5) The phrase "Keep your children away from smoking" affects older males and males of high income levels respectively.

\subsection{Third: The Effect of Smoking on Family Economics and General Health}

1) There is a general trend of increase in the average monthly household expenditure on smoking in dollars.

2) Smoking causes chronic chest diseases and there are very few successful attempts of quitting.

3) There is a general trend of increase in the chest diseases mortality against total mortality in Egypt.

\section{Study Recommendations}

1) The researcher believes it is necessary to integrate all administrative and psychological sciences to study and analyze the process governing human behaviour: starting from exposure to different warning messages, 
developing a conviction of the negative consequences of the behaviour and finally taking the decision whether to continue or quit the negative behaviour while being completely ware of any potential hazards.

2) It is recommended to stop unifying the warning messages directed towards consumers. They need to be adapted to the culture, age, education level and gender of the targeted groups.

3) Diversity of the communication channels is a must, as well as developing the content of warning messages and its language and its inclusiveness. This can be achieved via the media, advertising campaigns and awareness seminars held by doctors, scientists, men of religion, specialized research institutions, schools and universities according to the environments of the targeted groups.

4) In case of targeting smokers who are over 40 years old with warning messages, it is better to employ threats concerning children's health and also the negative roles and effects of friends.

5) It's recommended to direct threatening and intimidation warning messages via the media and advertising campaigns which target women in a manner that is different from the warning messages directed towards men on cigarette packs; it is better to use visual and audible communication means for better results.

6) It is imperative to pay attention to the form and content of readable, audio and visual warning messages; and to using effective images and colours, like blue which enhances feelings of fear... etc.

7) Diversifying warning messages directed to consumers is also important in order to avoid the familiarity that renders these messages ineffective; as well as providing evidence whenever possible.

8) Another important element that should be taken into consideration is the roles of friends, relatives and influencers in the lives of smokers; those individuals have a great power to push the individual either towards or away from smoking.

9) It's recommended to use the emotional marketing approach that employs threat and intimidation in a sequential and logical manner using rational arguments and real experiences and facts.

10) Drama and film must be reviewed where artists take on roles of heavy smokers.

11) Besides concentrating on immune deficiency diseases and cardiovascular diseases as potential health hazards of smoking, it is necessary to warn against hazards on the skin and beauty.

\section{References}

Agrawal, N., \& Duhachek, A. (2010). Emotional Compatibility And The Effectiveness Of Antidrinking Messages: A defensive processing perspective on shame and guilt. Journal of Marketing Research, 47(2), 263-273. https://doi.org/10.1509/jmkr.47.2.263

Ajzen, I. (1991). The Theory of Planned Behavior. Organizational Behavior and Human Decision Processes, 50(2), 179-211. https://doi.org/10.1016/0749-5978(91)90020-T

Andrews, J. C., Netemeyer, R. G., Kees, J., \& Burton, S. (2014). How Graphic Visual Health Warnings Affect Young Smokers' thoughts of quitting. Journal of Marketing Research, 51(2), 165-183. https://doi.org/10.1509/jmr.13.0092

Ansolabehere, S., \& Iyengar, S. (1995). Going Negative: How Attack Ads Shrink And Polarize The Electorate. New York, NY: The Free Press.

Antonetti, P., \& Baines, P. (2014). Guilt in Marketing Research: An Elicitation-Consumption Perspective and Research Agenda. International Journal of Management Reviews.

Antonetti, P., \& Maklan, S. (2014a). Feelings That Make A Difference: How Guilt And Pride Convince Consumers Of the Effectiveness Of Sustainable Consumption Choices. Journal of Business Ethics, 124(1), 117-134. https://doi.org/10.1007/s10551-013-1841-9

Antonetti, P., \& Maklan, S. (2014b). Exploring Post Consumption Guilt and Pride in the Context of Sustainability. Psychology and Marketing, 31(9), 717-735. https://doi.org/10.1002/mar.20730

Antonetti, P., Baines, P., \& Walker, L. (2015). From Elicitation to Consumption: Assessing the Longitudinal Effectiveness of Negative Emotional Appeals in Social Marketing. Journal of Marketing Management, 31(9-10), 940-969. https://doi.org/10.1080/0267257X.2015.1031266

Arab Republic of Egypt, Central Agency for Public Mobilization and Statistics, Research on Income, Spending and Consumption, from 2000 to 2017.

Arab Republic of Egypt, Central Agency for Public Mobilization and Statistics, Birth and Death, from 2000 to 
2017.

Arab Republic of Egypt, the Central Agency for Public Mobilization and Statistics, Statistical Yearbook, 2017.

Ashour, S. K., \& Fotouh, S. A. (2000). Statistical Sampling Methods. Cairo University.

Bagozzi, R. P., Gopinath, M., \& Nyer, P. U. (1999). The Role of Emotions in Marketing. Journal of the Academy of Marketing Science, 27(2), 184-206. https://doi.org/10.1177/0092070399272005

Baines, P. (2014). Guilt in Marketing Research: An Elicitation-Consumption Perspective and Research Agenda. International Journal of Management Reviews.

Dickinson, S., \& Holmes, M. (2008). Understanding The Emotional And Coping Responses of Adolescent Individuals Exposed To Threat Appeals. International Journal of Advertising, 27(2), 251-278. https://doi.org/10.1080/02650487.2008.11073054

Dillard, J. P., \& Peck, E. (2000). Affect and persuasion: Emotional Responses to Public Service Announcements. Communication Research, 27(4), 461-495. https://doi.org/10.1177/009365000027004003

Ferguson, G., \& Phau, I. (2013). Adolescent and Young Adult Response to Fear Appeals In Antismoking Messages. Young Consumers, 14(2), 155-166. https://doi.org/10.1108/17473611311325555

Finkenauer, C., \& Rimé, B. (1998). Socially Shared Emotional Experiences Vs. Emotional Experiences Kept Secret: Differential Characteristics And Consequences. Journal of Social and Clinical Psychology, 17(3), 295-318. https://doi.org/10.1521/jscp.1998.17.3.295

Friestad, M., \& Thorson, E. (1986). Emotion-eliciting advertising: Effects on long-term Memory and Judgment. Advances in Consumer Research, 13, 111-116.

Gallopel-Morvan, K., Gabriel, P., Le Gall-Ely, M., Rieunier, S., \& Urien, B. (2011). The Use of Visual Warnings in Social Marketing: The Case of Tobacco. Journal of Business Research, 64(1), 7-11. https://doi.org/10.1016/j.jbusres.2009.09.012

Godin, G. (1987). Importance of the Emotional Aspect of Attitude to Predict Intention. Psychological Reports, 61, 719-723. https://doi.org/10.2466/pr0.1987.61.3.719

Han, D., Duhachek, A., \& Agrawal, N. (2014). Emotions Shape Decisions Through Construal Level: The Case Of Guilt And Shame. Journal of Consumer Research, 41(4), 1047-1064. https://doi.org/10.1086/678300

Hastings, G. (2007). Social Marketing: Why Should The Devil Have All The Best Tunes? Oxford: Butterworth-Heinemann.

Hastings, G., Stead, M., \& Webb, J. (2004). Fear Appeals in Social Marketing: Strategic and Ethical Reasons for Concern. Psychology and Marketing, 21(11), 961-986. https://doi.org/10.1002/mar.20043

Johnson, S. (2013). Communicating Sustainability: Lessons from Public Health. Guardian Professional. Retrieved from http://www.theguardian.com/sustainable-business/communicating-sustainability-behavior-change-public-he alth.

Jones, C. R., Olson, M. A., \& Fazio, R. H. (2010). Evaluative Conditioning: The "how" question. Advances in Experimental Social-Psychology, 43, 205-255. https://doi.org/10.1016/S0065-2601(10)43005-1

Kim, J.-E., \& Johnson, K. K. P. (2013). The Impact Of moral Emotions on Cause-Related Marketing Campaigns: A cross-cultural examination. Journal of Business Ethics, 112(1), 79-90. https://doi.org/10.1007/s10551-012-1233-6

Lazarus, R. S. (1991). Emotion and Adaptation. Oxford: Oxford University Press.

Lazarus, R. S., \& Folkman, S. (1984). Stress, appraisal, and coping. New York, NY: Springer.

LeDoux, J. E., Romanski, L., \& Xagoraris, A. (1989). Indelibility of Subcortical Emotional Memories. Journal of Cognitive Neuroscience, 1(3), 238-243. https://doi.org/10.1162/jocn.1989.1.3.238

Lee, H. S., \& Park, J. S. (2012). Cultural Orientation and the Persuasive Effects of Fear Appeals: The Case of Anti-Smoking Public Service Announcements. Journal of Medical Marketing, 12(2), 73-80. https://doi.org/10.1177/1745790412443145

Lee, N. R., \& Kotler, P. (2011). Social marketing: Influencing Behaviors for Good (4th ed.). Sage Publications South Asia.

Lee-Wingate, S. N., Moon, J. Y., \& Bose, M. (2014). The Influence of Mortality Focus on Guilt Advertising 
Effectiveness. The Journal of Marketing Theory and Practice, 22(1), $103-114$. https://doi.org/10.2753/MTP1069-6679220107

Lennon, R., Rentfro, R., \& O’Leary, B. (2010). Social Marketing and Distracted Driving Behaviours among Young Adults: The Effectiveness of Fear Appeals. Academy of Marketing Studies Journal, 14(2), 95-113.

Lerner, J. S., \& Keltner, D. (2000). Beyond valence: Toward A Model of Emotion-Specific Influences on Judgment and Choice. Cognition and Emotion, 14(4), 473-493. https://doi.org/10.1080/026999300402763

Levine, L. J., \& Pizarro, D. A. (2004). Emotion and Memory Research: A Grumpy Overview. Social Cognition, 22(5), 530-554. https://doi.org/10.1521/soco.22.5.530.50767

Moors, A. (2009). Theories Of Emotion Causation: A review. Cognition and Emotion, $23(4), 625-662$. https://doi.org/10.1080/02699930802645739

Morales, A. C., Wu, E. C., \& Fitzsimons, G. J. (2012). How Disgust Enhances the Effectiveness Of fear Appeals. Journal of Marketing Research, 49(3), 383-393. https://doi.org/10.1509/jmr.07.0364

O’Keefe, D. J. (2000). Guilt and Social Influence. Communication Yearbook, 23, 67-101.

O’Keefe, D. J. (2002). Guilt as a Mechanism of Persuasion. In J. P. Dillard \& M. Pfau (Eds.), The persuasion Handbook: Developments in Theory and Practice (pp. 329-344). London: Sage. https://doi.org/10.4135/9781412976046.n17

Oatley, K. (1999). Why Fiction May Be Twice As True As Fact: Fiction As Cognitive And Emotional Simulation. Review of General Psychology, 3(2), 101-117. https://doi.org/10.1037/1089-2680.3.2.101

Oatley, K. (2002). Emotions and the Story Worlds of Fiction. In M. C. Green, J. J. Strange, \& T. C. Brock (Eds.), Narrative impact: Social and cognitive foundations (pp. 39-69). Mahwah, NJ, US: Lawrence Erlbaum Associates Publishers.

Olsen, L. E., Samuelsen, B. M., \& Gaustad, T. (2014). Same service, Different Ad Claims: The Moderating Role of Need for Cognition. Psychology and Marketing, 31(12), 1064-1073. https://doi.org/10.1002/mar.20753

Passyn, K., \& Sujan, M. (2006). Self-Accountability Emotions and Fear Appeals: Motivating Behavior. Journal of Consumer Research, 32(4), 583-589. https://doi.org/10.1086/500488

Peter, P. C., \& Honea, H. (2012). Targeting Social Messages with Emotions of Change: The Call for Optimism. Journal of Public Policy and Marketing, 31(2), 269-283. https://doi.org/10.1509/jppm.11.098

Rogers, R., \& Thistlethwaite, D. (1970). Effects of Fear Arousal and Reassurance on Attitude Change. Journal of Personality and Social Psychology, 15, 227-233. https://doi.org/10.1037/h0029437

Roseman, I. J., Antoniou, A. A., \& Jose, P. E. (1996). Appraisal Determinants of Emotions: Constructing More Accurate and Comprehensive Theory. Cognition and Emotion, 10(3), 241-278. https://doi.org/10.1080/026999396380240

Roseman, I. J., Spindel, M. S., \& Jose, P. E. (1990). Appraisals of Emotion-Eliciting Events: Testing a Theory of Discrete Emotions. Journal of Personality and Social Psychology, 59(5), 899-915. https://doi.org/10.1037/0022-3514.59.5.899

Roseman, I. J., Wiest, C., \& Swartz, T. S. (1994). Phenomenology, Behaviors, And Goals Differentiate Discrete Emotions. Journal of Personality and Social Psychology, 67(2), $206-221$. https://doi.org/10.1037/0022-3514.67.2.206

Samu, S., \& Bhatnagar, N. (2008). The Efficacy of Anti-Smoking Advertisements: The Role of Source, Message and Individual Characteristics. International Journal of Nonprofit and Voluntary Sector Marketing, 13(3), 237-250. https://doi.org/10.1002/nvsm.326

Stainback, R., \& Rogers, R. W. (1983). Identifying Effective Components of Alcohol Abuse Prevention Programs: Effects Of fear Appeals, Message Style and Source Expertise. International Journal of Addictions, 18(3), 393-405. https://doi.org/10.3109/10826088309039356

Stanton, J. V., \& Guion, D. T. (2013). Taking Advantage of a Vulnerable Group? Emotional Cues in Ads Targeting Parents. Journal of Consumer Affairs, 47(3), 485-517. https://doi.org/10.1111/joca.12018

Steenhaut, S., \& Van Kenhove, P. (2006). The Mediating Role of Anticipated Guilt in Consumers' Ethical Decision-Making. Journal of Business Ethics, 69(3), 269-288. https://doi.org/10.1007/s10551-006-9090-9

Tangney, J. P., Stuewig, J., \& Mashek, D. J. (2007). Moral Emotions and Moral Behavior. Annual Review of 
Psychology, 58, 345-372. https://doi.org/10.1146/annurev.psych.56.091103.070145

Zajonc, R. (1980). Feeling And Thinking: Preferences Need No Inferences. American Psychologist, 35, 151-175. https://doi.org/10.1037/0003-066X.35.2.151

Zajonc, R. (1998). Emotions. In D. T. Gilbert, S. T. Fiske, and G. Lindzey (Eds.), The Handbook of Social Psychology (4th ed., Vol. 2, pp. 591-632).

\section{Copyrights}

Copyright for this article is retained by the author, with first publication rights granted to the journal.

This is an open-access article distributed under the terms and conditions of the Creative Commons Attribution license (http://creativecommons.org/licenses/by/4.0/). 